\title{
Benefits of organic olive rainfed systems to control soil erosion and runoff and improve soil health restoration
}

\author{
Víctor Hugo Durán Zuazo ${ }^{1}$ (1) • Belén Cárceles Rodríguez ${ }^{1}$ Iván Francisco García-Tejero ${ }^{2}$ Baltasar Gálvez Ruiz ${ }^{1}$. \\ Simón Cuadros Tavira ${ }^{3}$
}

Accepted: 4 October 2020 / Published online: 27 October 2020

(C) INRAE and Springer-Verlag France SAS, part of Springer Nature 2020

\begin{abstract}
The soil erosion rates are high in the rainfed olive (Olea europaea L.) mountain plantations applying conventional practices in a semi-arid Mediterranean environment, which compromise their long-term sustainability. The implementation of sustainable soil management strategies is vital for hillslopes and low-fertility soils where plantations cover vast tracts of land. In Lanjarón (Granada, Spain), the soil erosion and runoff patterns over a 4-year monitoring period were studied in erosion plots on a mountainside under four types of production systems: (1) organic (spontaneous vegetation and leguminous covers), (2) conservation agriculture (combinations of minimum tillage with spontaneous and leguminous strips), (3) integrated (combinations of no-tillage with spontaneous vegetation and leguminous strips), and (4) conventional tillage. The olive yield responses to each production system were evaluated, and the selected physico-chemical soil properties $(\mathrm{pH}$, bulk density, soil organic carbon, cation exchange capacity, and total N, P, and K), soil enzymes ( $\beta$-glucosidase, protease, dehydrogenase, and phosphatase activities), and soil-microbial biomass $\mathrm{C}$ and $\mathrm{N}$ were monitored. Throughout the study period, the erosion rates for organic, conservation, integrated, and conventional systems averaged $0.70,2.10,1.52$, and $3.25 \mathrm{tha}^{-1}$ year $^{-1}$ with runoff of 5.8, 6.3, 11.9, and $17.6 \mathrm{~mm}_{\text {year }}{ }^{-1}$, respectively. The mean olive yield was not significantly affected by the production system applied, being 2.43, 2.10, 2.04, and $2.11 \mathrm{t} \mathrm{ha}^{-1}$ year $^{-1}$ for integrated, organic, conservation, and conventional, respectively. Here, we show a substantial improvement in soil health restoration using the organic rather than a conventional system. Our findings suggest that sustainable cropping systems on hillslopes integrating a blend between organic and conventional doctrines better maintain or improve soil ecosystem functioning. This study highlights a balanced design for an integrated production system for rainfed olive orchards that can maintain productivity while suitably encouraging environmental quality and ecosystem services.
\end{abstract}

Keywords Rainfed olive orchard · Soil management strategies $\cdot$ Soil quality $\cdot$ Water erosion $\cdot$ Runoff

\section{Introduction}

The olive tree (Olea europaea L.) is one of the most typical and economically important crops in the Mediterranean basin,

Víctor Hugo Durán Zuazo

victorh.duran@juntadeandalucia.es

1 IFAPA Centro "Camino de Purchil", Camino de Purchil s/n, 18004 Granada, Spain

2 IFAPA Centro "Las Torres", Carretera Sevilla-Alcalá del Río km 12,2, 41200, Alcalá del Río, Sevilla, Spain

3 Depto. Ingeniería Forestal, Universidad de Córdoba, Campus de Rabanales, E-14071 Córdoba, Spain representing a significant part of the environment since ancient times (Efe 2012). At present, olive plantations cover about 10 Mha worldwide, of which more than 2.73 Mha of olives are grown in Spain. Despite the recent expansion of irrigation, most of the cultivated area is under rainfed conditions (1.89 Mha, 69\%) (ESYRCE 2019). In this context, the cultivation of olives is concentrated in southern Spain (Andalusia) with 1.65 Mha, where many rainfed orchards $(61 \%)$ are confined to slopes or rugged land, occupying large parts of mountains and hills (Sánchez and Paniza 2015) (Fig. 1). The main constraint in these areas is the shortage of soil-water content to promote cultivation under low plant density, transpiration control by reducing the canopy crown size through periodic pruning, and weed control by tillage and/or herbicide use. This constraint combined with the poor vegetation cover of the soil increases 

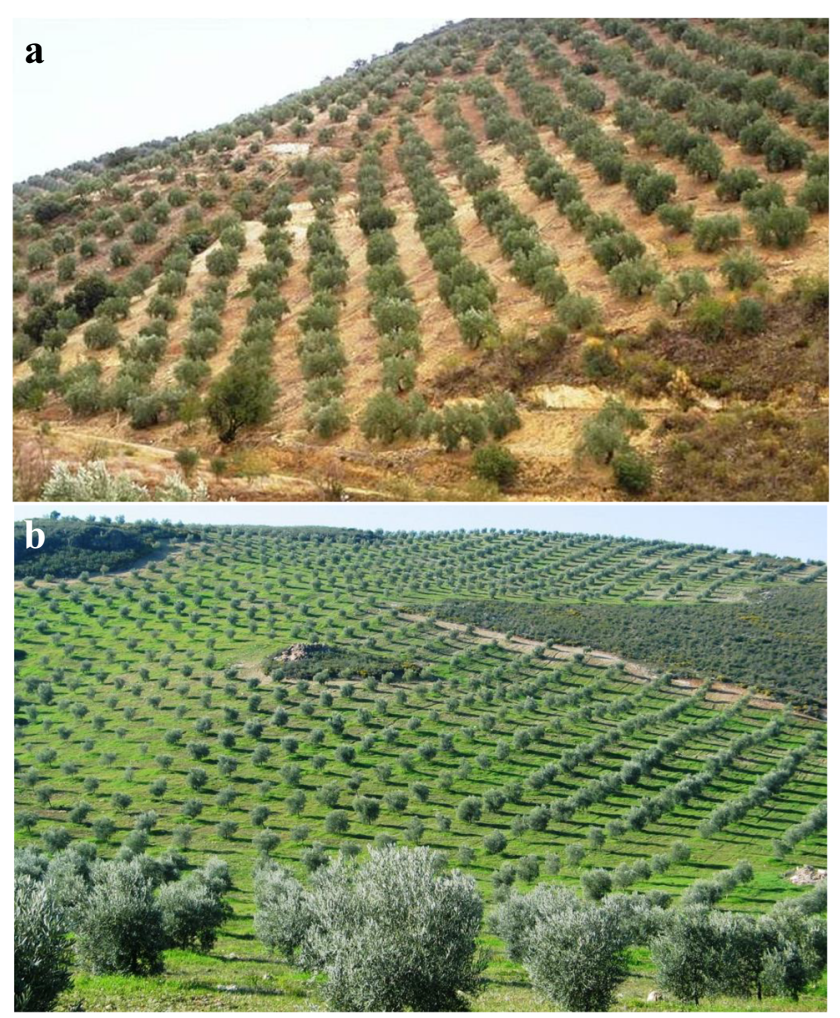

Fig. 1 Rainfed mountainous olive plantations in high (A) and moderate (B) hillslopes in Andalucia (S Spain)

the area's vulnerability to water erosion and, therefore, complicates successful soil rehabilitation (Durán and Rodríguez 2008; Gómez 2017).

According to Vanwalleghem et al. (2011), the average soil erosion for the widely spaced olive trees on the slopes in southern Spain range from 29 to $47 \mathrm{t} \mathrm{ha}^{-1}$ year $^{-1}$. Several studies focus on the impact of soil management systems on soil erosion in olive plantations in different Mediterranean areas (Karydas et al. 2009; Durán et al. 2009a; Gómez et al. 2014).

Agricultural production systems are a set of strategies used to manage the available resources to achieve economic and sustainable agricultural productivity to meet the needs of humans, while also preserving resources and maintaining the environment (Beaufoy 2001). Common systems include conventional, organic, conservation, and integrated systems. Soil tillage plays an important role in agricultural soil management, and many olive orchards use conventional tillage to reduce the competition between trees and weeds for soilwater uptake (López and Álvarez 2018). Conventional tillage creates roughness and may affect surface runoff and erosion patterns. In such an environment, rainwater needs to be wholly harvested, and unnecessary runoff losses should be minimized (Oweis and Hachum 2009; Durán et al. 2009b). In this context, conservation tillage (minimum tillage) is applied as an alternative to conventional tillage to mitigate water erosion impacts, reduce production costs, and maintain soil quality (Subbulakshmi et al. 2009).

An organic system implies the permanent maintenance of plant cover with mechanical control or grazing livestock. In contrast to a conventional system, the organic system protects and preserves biodiversity, biological cycles, and natural soil activity. It also minimizes off-farm inputs while no longer exclusively supporting yields but also the quality, health, and environmental aspects of the products (Rodríguez et al. 2018).

The integrated production system for olive plantations explores the synergies arising from the interactions among its components, seeking to increase its efficiency of land use and its economic margins (Beaufoy 2001). For this reason, the conditions for integrated production must include criteria related to soil and water conservation and fertilization and not merely to rational pest control. In particular, tillage operations are forbidden in slopes equal to or greater than $10 \%$. However, such slopes may be developed at a depth not greater than 20 $\mathrm{cm}$. Natural vegetation covers should be preserved to encourage soil conservation and biodiversity (BOJA 2008).

In this context, cover crops have many uses, including controlling soil erosion, augmenting the soil organic matter amount, enhancing the nitrogen balance and physicobiochemical soil properties, improving soil-water content, suppressing weeds, and improving biodiversity, among others (Soriano et al. 2014; Sánchez et al. 2015). Cover crops on sloping lands with rainfed fruit crops are not a common practice primarily because they do not result in an economic return; however, the environmental return is highly important (Milgroom et al. 2007). Cover crops compete for resources (plant nutrients and water) with trees, which can lead to a decline in productivity (Arampatzis et al. 2018).

Healthy soils are vital for terrestrial ecosystems to remain intact or recover from the disturbances provoked by agricultural activities, particularly soil management. In this study, we examined various soil management strategies during four seasons (2015-2018) under different agricultural production systems for rainfed olive orchards in steeply sloping areas (Granada, SE Spain): organic, conservation agriculture, integrated, and conventional systems. The objective was to determine and compare the effects of these strategies for each system on soil erosion, runoff, olive productivity, and soil health restoration under the experimental conditions of a semi-arid Mediterranean environment.

\section{Materials and methods}

\subsection{Site description and soil management strategies}

This study was conducted in an olive orchard located in Lanjaron (Granada, SE Spain) with UTM coordinates of 
$X=456,747.60 ; Y=4,084,354.5$ at $565 \mathrm{~m}$ a.s.1.. The soils in the experimental area were typical xerorthent with a loamy soil texture $\left(550 \mathrm{~g} \mathrm{~kg}^{-1}\right.$ sand, $250 \mathrm{~g} \mathrm{~kg}^{-1}$ silt, and $200 \mathrm{~g} \mathrm{~kg}^{-1}$ clay).

Table 1 shows the soil management strategies applied to each agricultural production system during the 4-year monitoring period. The experimental plots used were part of a rainfed plantation 65-year-old of olive trees (Olea europaea cv. Picual) spaced $8 \times 8 \mathrm{~m}\left(<154\right.$ trees $\left.^{-1}\right)$. The erosion plots replicated twice for each soil management strategy were located on a mountain slope of $20 \%$. The plots were $192 \mathrm{~m}^{2}$ $(32 \mathrm{~m} \times 6 \mathrm{~m})$ and contained four trees each for monitoring the interrill erosion. Each erosion plot consisted of a galvanized enclosure, a drawer collector, and sediment and runoff collectors.

During the four seasons, appropriate routine cultivation techniques for each production system were applied to the olive production cycle, as shown in Table 1.

The native spontaneous vegetation in the study zone was mainly composed of the following plant species: Avena sativa L., Armeria sp., Anagallis arvensis L., Bromus madritensis L. Cent., Brachypodium sp., Calendula arvensis L., Campanula sp., Convolvulus althaeoides L., Crepis sp., Diplotaxis virgata (Cav) DC, Malva parviflora L., Phagnalon rupestre L. DC, Velezia rígida L., Medicago sp., Papaver rhoeas L., Rapistrum rugosum L. All, Scabiosa sp., Sisymbrium sp.,
Sonchus arvensis L., and Trigonella monspeliaca L. This vegetation was planted a year before the beginning of this study, allowing us to colonize them. In addition, a small strip ( $1 \mathrm{~m}$ width) was retained without mowing to ensure self-seeding. After engaging in plant cover control via mechanical mowing, the debris was left on the soil surface for mulching.

\subsection{Field and laboratory measurements and statistical analysis}

We continuously monitored weather conditions during the study period from 2015 to 2018 . The rainfall data were continuously recorded every $2 \mathrm{~min}$ from an automatic weather station, and the average intensity ( $I=$ (total rain/total time) $\left.\left(\mathrm{mm} \mathrm{h}^{-1}\right)\right)$ and maximum intensity at $30 \mathrm{~min}\left(I_{30}\right)$ were estimated. From these data, the erosivity index $\left(\mathrm{EI}_{30}\right)$ was calculated (Wischmeier and Smith 1978). Throughout the rainy period, the soil erosion and runoff from the plots were collected and measured after each rainfall event.

At the end of each season, the olive yield from eight trees was harvested by hand for each soil management strategy and averaged in terms of the production systems.

Soil samples from the experimental plots were taken in 2016 and 2018 after a year of soil treatments in the field and at two sites, underneath the plant strip and in the inter-row (tilled soil). Three sampling points were selected inside the

Table 1 Soil-management strategies for each olive production system studied

\begin{tabular}{|c|c|c|c|c|}
\hline $\begin{array}{l}\text { Production } \\
\text { system }\end{array}$ & Soil management strategy & Autumn & Winter & Spring \\
\hline \multirow[t]{2}{*}{ Organic } & $\begin{array}{l}\text { No-tillage and spontaneous } \\
\text { vegetation cover for entire } \\
\text { soil surface (SVC) }\end{array}$ & Self-seeding and olive harvest & None & $\begin{array}{l}\text { Mechanical } \\
\text { vegetation } \\
\text { cover control }\end{array}$ \\
\hline & $\begin{array}{l}\text { No-tillage and legume cover } \\
\text { for entire soil surface (LEC) }\end{array}$ & $\begin{array}{l}\text { Sowing of legume cover }\left(200 \mathrm{~kg} \mathrm{ha}^{-1}\right) \\
\text { and olive harvest }\end{array}$ & None & $\begin{array}{l}\text { Mechanical } \\
\text { vegetation } \\
\text { cover control }\end{array}$ \\
\hline \multirow[t]{2}{*}{ Conservation } & $\begin{array}{l}\text { Minimum tillage with } \\
\text { spontaneous } \\
\text { vegetation strips (MSS) }\end{array}$ & $\begin{array}{l}\text { Minimum tillage }(10 \mathrm{~cm}) \text {, self-seeding } \\
\text { plant strips } 3 \mathrm{~m} \text { wide and olive harvest. } \\
15-15-15 \mathrm{NPK}^{-1} 453.2 \mathrm{~kg} \mathrm{ha}^{-1} \text { and urea } \\
301.5 \mathrm{~kg} \mathrm{ha}^{-1} \text { year }^{-1}\end{array}$ & None & $\begin{array}{l}\text { Mechanical plant } \\
\text { strip control }\end{array}$ \\
\hline & $\begin{array}{l}\text { Minimum tillage with } \\
\text { legume strips (MLS) }\end{array}$ & $\begin{array}{l}\text { Minimum tillage }(10 \mathrm{~cm}) \text {, sowing legume } \\
\text { strips } 3 \mathrm{~m} \text { wide }\left(200 \mathrm{~kg} \mathrm{ha}^{-1}\right) \text {, and olive } \\
\text { harvest. } 15-15-15 \mathrm{NPK} \text { at } 453.2 \mathrm{~kg} \mathrm{ha}^{-1} \\
\text { and urea } 301.5 \mathrm{~kg} \mathrm{ha}^{-1} \text { year }\end{array}$ & None & $\begin{array}{l}\text { Mechanical plant } \\
\text { strip control }\end{array}$ \\
\hline \multirow[t]{2}{*}{ Integrated } & $\begin{array}{l}\text { No-tillage with spontaneous } \\
\text { vegetation strips (NSS) }\end{array}$ & $\begin{array}{l}\text { No-tillage, self-seeding plant strips } 3 \text { m wide } \\
\text { and olive harvest. } 15-15-15 \mathrm{NPK} \text { at } 226.6 \\
\mathrm{~kg} \mathrm{ha}^{-1} \text { and urea } 150.8 \mathrm{~kg} \mathrm{ha}^{-1} \text { year }^{-1}\end{array}$ & None & $\begin{array}{l}\text { Herbicide glyphosate } \\
\text { application } \\
\left(2.0 \mathrm{~L} \mathrm{ha}^{-1}\right)\end{array}$ \\
\hline & $\begin{array}{l}\text { No-tillage with legume } \\
\text { strips (NLS) }\end{array}$ & $\begin{array}{l}\text { No-tillage, sowing legume strips } 3 \mathrm{~m} \text { wide } \\
\left(200 \mathrm{~kg} \mathrm{ha}^{-1}\right), \text { and olive harvest. } 15-15-15 \\
\text { NPK at } 226.6 \mathrm{~kg} \mathrm{ha}^{-1} \text { and urea } 150.8 \mathrm{~kg} \\
\text { ha }^{-1} \text { year }\end{array}$ & None & $\begin{array}{l}\text { Herbicide glyphosate } \\
\text { application } \\
\left(2.0 \mathrm{~L} \mathrm{ha}^{-1}\right)\end{array}$ \\
\hline Conventional & $\begin{array}{l}\text { Conventional tillage without } \\
\text { plant covers }(\mathrm{CT})\end{array}$ & $\begin{array}{l}\text { Mouldboard tillage }(25 \mathrm{~cm}) \text { and olive } \\
\text { harvest. } 15-15-15 \mathrm{NPK} \text { at } 453.2 \\
\mathrm{~kg} \mathrm{ha}^{-1} \text { and urea } 301.5 \mathrm{~kg} \mathrm{ha}^{-1} \text { year }^{-1}\end{array}$ & $\begin{array}{l}\text { Pre-emergence } \\
\text { herbicide } \\
\text { Oxifluorfen } \\
\left(3 \mathrm{~L} \mathrm{ha}^{-1}\right)\end{array}$ & $\begin{array}{l}\text { Herbicide glyphosate } \\
\text { application } \\
\left(4.0 \mathrm{~L} \mathrm{ha}^{-1}\right)\end{array}$ \\
\hline
\end{tabular}


plot and four composite soil samples were collected from the topsoil (at 0-10 and 10-20 cm) along the experimental plot. A similar procedure was followed for bulk density with an undisturbed soil core sample at $10-\mathrm{cm}$ intervals in the top $30 \mathrm{~cm}$. The investigated soil parameters included soil organic carbon, total N, extractable P (Olsen), available $\mathrm{K}$, cation exchange capacity (CEC), and $\mathrm{pH}(1: 2.5)$, according to the standard methods (MAPA 1986). For the assessment of macroporosity, 5 undisturbed soil samples were saturated with water via capillarity in a sandbox to determine the soil matric potential ( $\mathrm{pF})$ $(0.1$ to $6.3 \mathrm{kPa})$.

The soil microbial biomass carbon $\left(\mathrm{MB}_{\mathrm{C}}\right)$ and nitrogen $\left(\mathrm{MB}_{\mathrm{N}}\right)$ were estimated for fresh soil samples using chloroform fumigation extraction according to Vance et al. (1987) after $24 \mathrm{~h}$ (at $25^{\circ} \mathrm{C}$ with $60 \%$ water holding capacity). Soil enzyme activities were analyzed on air-dried samples, and $\beta$-glucosidase and phosphatase as $\mu \mathrm{g} \mathrm{p}$ nitrophenol $(p \mathrm{NP}) \mathrm{g}^{-1} \mathrm{~h}^{-1}$. Protease activity was determined following the procedure by Kandeler (1995), with a casein substrate and equivalents of tyrosine (TRS) after $2 \mathrm{~h}$ at $50{ }^{\circ} \mathrm{C}$, and dehydrogenase was studied according to Casida et al. (1964).

According to the analysis of variance (ANOVA), the means of the different effects of the soil management strategies were compared, and differences between individual means were tested using a least statistical difference (LSD) test at $p<0.05$. A correlation matrix based on Pearson's coefficients was fitted between physico-chemical parameters and enzymatic activities.

\section{Results and discussion}

\subsection{Rainfall characteristics}

During the 4 years of monitoring, 33 rainfall events occurred. The storm during the first year produced $91.3 \mathrm{~mm}$ of rain $(8$ September 2015) with the highest intensity $\left(I_{30}\right)$ and erosivity index $\left(\mathrm{EI}_{30}\right)$ of $107.6 \mathrm{~mm} \mathrm{~h}^{-1}$ and $2719.9 \mathrm{MJ} \mathrm{mm} \mathrm{ha}^{-1} \mathrm{~h}^{-1}$, respectively. This event contrasts the event with $183.5 \mathrm{~mm}$ during the fourth year, with an $I_{30}$ and $\mathrm{E} I_{30}$ of $14.6 \mathrm{~mm} \mathrm{~h}^{-1}$ and 523.3 $\mathrm{MJ} \mathrm{mm} \mathrm{ha}{ }^{-1} \mathrm{~h}^{-1}$, respectively. These results are much lower than those of the first year (five and sevenfold, respectively) in their rainfall energy, illustrating high annual and inter-annual differences in both quantity and intensity. Specifically, the erosivity indexes during the 4-year monitoring period varied considerably, ranging from 3.9 to $2719.9 \mathrm{MJ}$ $\mathrm{mm} \mathrm{ha}{ }^{-1} \mathrm{~h}^{-1}$, with intensity from 3.7 to $107.6 \mathrm{~mm} \mathrm{~h}^{-1}$. This variability was associated with high erosive rainfall in the Mediterranean. Additionally, the total rainfall amounts per year during the monitoring period $(320.7,225.1,183.8$, and $357.2 \mathrm{~mm}$ ) were lower than those considered as the average rainfall $(490 \mathrm{~mm})$ in the study zone. This demonstrates the peculiar annual and seasonal patterns of the changing Mediterranean climate, which features many heavy rainfall events, as described by Seubert et al. (2014).

Except for the heavy rainfall, the remaining 32 events could be considered regular events in the study area. That is, the main factor affecting the vulnerability of the Mediterranean region to water erosion was the high intensity of the rainfall after dry summers, and the high rainfall fluctuations over the short and long term. Therefore, water erosion is intimately linked to climate characteristics and land use. For the Mediterranean basin, the following environmental scenarios forecast an augmentation in temperature and a reduction in precipitation (likely accompanied by an increase in intensity), as with this heavy rainfall event (Piacentini et al. 2018). In this context, soil management strategies should stress the factors that are strongly influenced by agricultural activities - that is, land cover and soil use, to mitigate the impact of such extreme events.

\subsection{Soil erosion and runoff responses to soil management strategies}

The soil erosion and runoff rates are provoked by the 33 rainfall events over the 4-year monitoring period, including those that were recorded from the extreme rainfall event during the first season. The results show that during 2014-2015, the runoff rates were lower for the conservation agriculture strategies, particularly for minimum tillage with spontaneous vegetation strips (MSS) and minimum tillage with legume strips (MLS), with the highest rates observed for conventional tillage (CT) followed by integrated strategies with no-tillage and spontaneous vegetation strips (NSS) and no-tillage with legume strips (NLS). During the second and third seasons, the lowest runoff rate was found for the no-tillage and legume cover of the entire soil surface (LEC) and for the fourth no-tillage and spontaneous vegetation cover for the entire soil surface (SVC), both under the organic system. Overall, in average terms, the runoff reached similar rates under the organic and conservation systems (5.78 vs. $6.32 \mathrm{~mm}$ ). Concretely, the mean annual runoff for the soil management strategies of SVC, LEC, MSS, MLS, NSS, NLS, and CT amounted to $5.0,6.6,5.5,7.1,12.3,11.4$, and $17.6 \mathrm{~mm}$ year $^{-1}$, ,espectively, averaged in terms of the production systems for organic, conservation, integrated, and conventional systems, with 5.8, 6.3, 11.9, and $17.6 \mathrm{~mm} \mathrm{year}^{-1}$, respectively. In other words, the organic system, compared with the conservation, integrated, and conventional systems, lowered runoff by $8 \%, 51 \%$, and $67 \%$, respectively. Plant cover reduced the velocity of flowing water by retarding and spreading the concentrated surface runoff, which boosted the sediment deposition and upslope of the leguminous or spontaneously growing native plant strips. The plant strips trapped the surface runoff and temporarily stored it in the soil matrix. This might be the first step in 
improving the rainwater-use efficiency in rainfed systems. A similar reduction effect for runoff rates from olive hillslope orchards with cover crops and conventional tillage (44.0 and $83.0 \mathrm{~mm}$ year $^{-1}$, respectively) was reported by Gómez et al. (2010). The higher rates in runoff in conventional and integrated systems could increase nutrient loss from applied fertilizers (highly soluble) and transport toward lower levels as was highlighted by Francia et al. (2006). This can compromise olive productivity.

For soil erosion under different soil management strategies, the highest rate was achieved with CT. Specifically, during the first season (2015), an important soil erosion control was produced by the LEC and NSS strategies for organic and integrated systems, respectively. Throughout the second, third, and fourth seasons, the lowest values for soil erosion were found using the MSS, SVC, and NSS strategies. Therefore, with the exception of the first season, the production system increased soil erosion in the following order: conventional > integrated $>$ conservation $>$ organic. However, by considering the soil erosion for the entire monitoring seasons, the average differed due to heavy rainfall events, which had the highest rate in conventional system, followed by conservation agriculture and integrated, whereas organic strategies produced the lowest rate. For the whole study period, the mean soil erosion rates from SVC, LEC, MSS, MLS, NSS, NLS, and CT were $1070.1,322.9,2044.1,2147.9,542.3,2497.3$, and $3247.5 \mathrm{~kg}$ ha $^{-1}$ year ${ }^{-1}$, respectively; therefore, the averaged values for organic, conservation, integrated, and conventional systems were $0.70,2.10,1.52$, and $3.25 \mathrm{t} \mathrm{ha}^{-1}$ year ${ }^{-1}$, respectively. Consequently, in average terms, the organic system reduced soil erosion compared with the conservation, integrated, and conventional systems (by 67\%, 54\%, and 78\%, respectively).

In short, under the effect of the production systems throughout the four hydrological years, the trend in runoff followed a decreasing pattern of conventional $>$ integrated $>$ conservation $>$ organic; which for soil erosion was conventional $>$ conservation $>$ integrated $>$ organic. That is, the response of soil erosion and runoff to soil management strategies was the same over the entire study period, with the highest values found using the conventional system and the lowest under organic strategies.

Under minimum tillage (MSS and MLS), the reduction in the runoff pattern could be mainly ascribed to the cracks in the soil surface that facilitated infiltration and pore connectivity more than in the conventional system. Soils under minimum tillage were less prone to sealing, and better efficiency was found for soil erosion reduction, which was also noted by Leys et al. (2007).

The greater soil erosion with the conventional system than the organic-type with permanent legume cover (SVC and LEC, 82.8 and $0.7 \mathrm{t} \mathrm{ha}^{-1}$, respectively) was also highlighted by Raglione et al. (1999). Kraushaar et al. (2014) estimated the potential soil erosion in olive orchards as $95.0 \pm 8.0 \mathrm{tha}^{-1}$ year $^{-1}$ since the tillage practices produced much higher rates than those found in this study. Gómez et al. (2009) reported the soil erosion rates for no-tillage, conventional tillage, and cover crops $\left(6.9,2.9\right.$, and $0.8 \mathrm{t} \mathrm{ha}^{-1}$ year ${ }^{-1}$, respectively), in contrast with another study that reported 1.70 and $31.0 \mathrm{t} \mathrm{ha}^{-1}$ year $^{-1}$ for cover crops and conventional tillage, respectively (Gómez et al. 2010). In the study area, Francia et al. (2006) found erosion values for no-tillage, conventional tillage, and cover crops of 25.6, 5.7, and $2.1 \mathrm{t} \mathrm{ha}^{-1}$ year $^{-1}$, respectively. That is, the use of conservation tillage (minimum tillage and no-tillage), which leaves the soil covered by crop residues is a suitable measure for lessening soil erosion. Thus, given their potential for reducing soil degradation, conservation tillage practices are vital in soils with a high risk of water erosion in vast rainfed areas.

The results of ANOVA for the effect of the soil management strategies on the average soil erosion and runoff without considering the heavy rainfall event are shown in Fig. $2 \mathrm{a}$ and $2 \mathrm{bbb}$. The soil erosion and runoff values for the different strategies differed significantly $(p<0.05)$ from those using conventional tillage. Water erosion was prevented by plant strips that run perpendicular to the slope, thereby trapping eroded soil, and decreasing the downslope runoff. The lowest average soil erosion and runoff rates were found for the MSS in the conservation agriculture system, followed by the organic system, with LEC and SVC on an event basis. The soil erosion and runoff were greater in the first and last hydrological years (2014-2015 and 2017-2018), which is in line with the high values for rainfall intensity and erosivity energy during both periods.

The results suggested that a combination of conservation tillage (no-tillage and minimum tillage) and plant strips notably decreased soil erosion by reducing surface runoff; the rainfall energy was dissipated twice by soil roughness and plant strips. The beneficial soil hydraulic functions of minimum tillage for non-tilled soil in olive orchards were reported by Castellini et al. (2020).

The average soil erosion rate was practically doubled by the effect of the NLS (16.2 $\left.\mathrm{kg} \mathrm{ha}^{-1}\right)$ for leguminous strips compared with NSS $\left(7.38 \mathrm{~kg} \mathrm{ha}^{-1}\right)$ and for spontaneously growing native plant strips, which could be associated with the types of plants used in the strips (Fig. 2a). In this context, according to Lindstrom and Onstad (1984), the notillage system (bare soil with herbicide application) creates undesirable surface conditions with low saturated hydraulic conductivity and a low volume of macropores, resulting in soil surface sealing and augmented runoff volume and flow velocity. Undoubtedly, soil tillage provides better temporary porosity that can delay surface sealing development during the beginning of the rainy period. In our experiment, the runoff rates from tilled soil swiftly decreased 


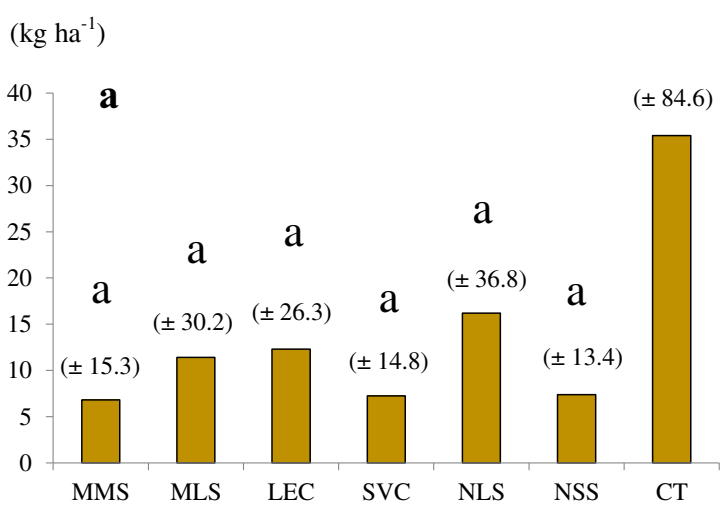

$\left(\mathrm{t} \mathrm{ha}^{-1}\right)$

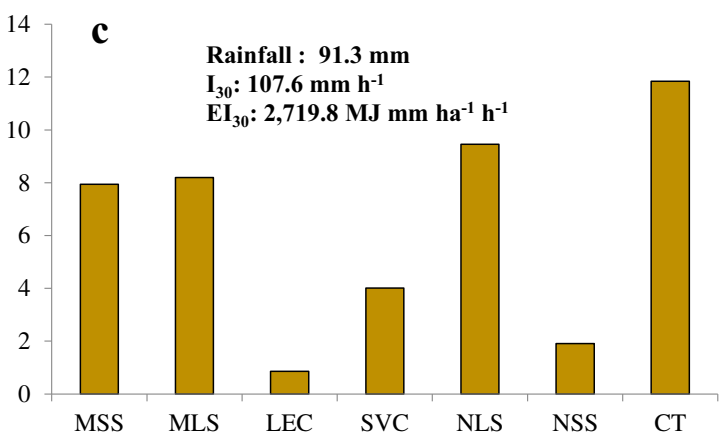

Fig. 2 Average soil erosion (a) and runoff (b) responses to soilmanagement strategies without considering extreme event and the total soil erosion (c) and runoff (d) rates triggered by the effect of a single heavy rainfall event. SVC, no-tillage and spontaneous vegetation cover for the entire soil surface; LEC, no-tillage and legume cover for the entire soil surface; MSS, minimum tillage with spontaneous vegetation strips;

after tillage operations but increased again following several rainstorms without tillage.

The lowest accumulated runoff during the study period was recorded in the MSS plot as $66.2 \mathrm{~mm}$ (the conservation agriculture system), followed by SVC and MLS with 67.5 and $75.9 \mathrm{~mm}$, respectively, in contrast to the $209.5 \mathrm{~mm}$ from conventional tillage over the experimental period. Comparably, the highest cumulative soil erosion value was found for conventional tillage at $50.2 \mathrm{t} \mathrm{ha}^{-1}$. However, the lowest for the LEC plot was $4.6 \mathrm{t} \mathrm{ha}^{-1}$ (organic system) followed by NSS (integrated system) and SVC (organic system), at 8.5 and 17.0 $\mathrm{t} \mathrm{ha}^{-1}$, respectively.

Regarding the relationships between rainfall characteristics, soil erosion, runoff, and production systems, we found that runoff is linearly related to rainfall depth, especially in the conservation, integrated, and conventional systems (from 0.878 to $0.905, p<0.01$ ), albeit to a lesser degree than the organic system $(0.573, p<0.05)$. Similarly, soil erosion was correlated with rainfall under all systems (from 0.644 to 0.796 , $p<0.01$ ). Significant relationships were found for the erosivity index $\left(\mathrm{EI}_{30}\right)$ compared with the erosion and runoff, which were the strongest for the integrated system $(0.915$ and 0.894 , $p<0.01)$. This result is in line with the findings discussed in $(\mathrm{mm})$

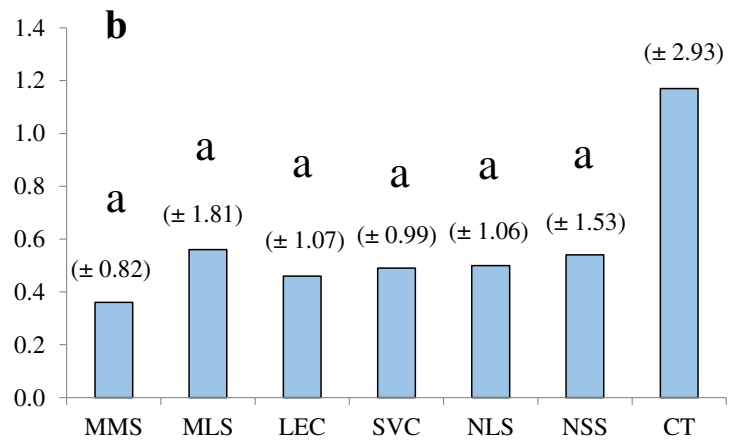

$(\mathrm{mm})$

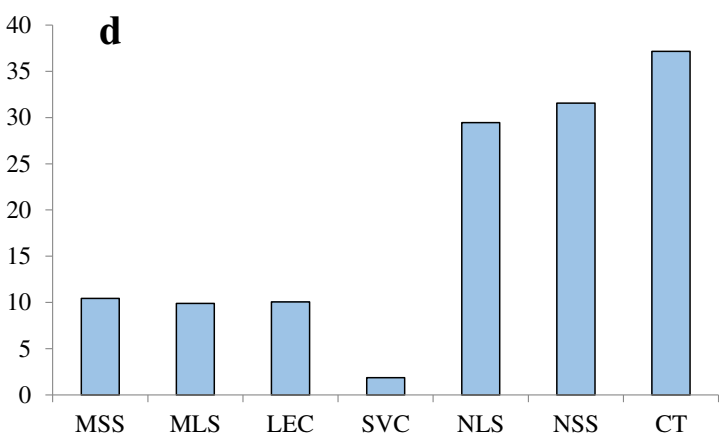

MLS, minimum tillage with legume strips, NSS, no-tillage with spontaneous vegetation strips, NLS, no-tillage with legume strips, CT, conventional tillage without plant covers. Values in parenthesis are the standard deviation, and values with different letters are statistically different $(p<0.05$; LSD)

previous sections. In contrast, the maximum rainfall intensity $\left(I_{30}\right)$ was highest related to soil erosion than to runoff. In general, the fit of the runoff versus soil erosion showed a significant correlation in all production systems, particularly for conservation agriculture, integrated, and conventional systems $(0.926,0.925$, and $0.901(p<0.01)$, respectively).

As soil erosion and runoff over the course of a storm are markedly affected by intra-storm fluctuations in rainfall intensity, the ordinary events were analyzed without considering extreme events. Mohamadi and Kavian (2015) revealed that, for lower rainfall intensities, a linear function better fits the relationship between soil erosion and rainfall intensity, whereas this function tends to be non-linear at higher intensities. The high variability of the rainfall and its intensity during the seasons produced a wide range of soil erosion and runoff results. However, despite this variability in rainfall events, soil erosion was highly dependent on runoff, with this trend more pronounced for the conservation, integrated, and conventional systems than for the organic system. 


\subsubsection{Extreme rainfall event}

The rainfall event that occurred in September 2015 registered as $91.3 \mathrm{~mm}$, with a maximum intensity in $30 \mathrm{~min}\left(I_{30}\right)$ periods of up to $107.6 \mathrm{~mm} \mathrm{~h}^{-1}$. The erosivity index $\left(\mathrm{EI}_{30}\right)$ amounted to $2719.8 \mathrm{MJ} \mathrm{mm} \mathrm{ha}^{-1} \mathrm{~mm} \mathrm{~h}^{-1}$, which is 42 times greater than the average annual value. In this context, for Mediterranean conditions, Martínez et al. (2002) reported extreme rainfall events with maximum intensities at $30 \mathrm{~min}$ and erosivity indexes of $205 \mathrm{~mm}, 91.8 \mathrm{~mm} \mathrm{~h}^{-1}$, and 11,756 $\mathrm{MJ} \mathrm{mm} \mathrm{ha}^{-1} \mathrm{~h}^{-1}$. These erosivity index results are much higher than those found in the present study. According to Panagos et al. (2015), extreme events with high intensity are one of the distinctive features of the Mediterranean climate. Such events represent a high percentage of annual rainfall and are one of the primary triggers of water erosion in the Mediterranean, with this region having the highest rainfall erosivity factor $(R>1000 \mathrm{MJ} \mathrm{mm}$ $\mathrm{ha}^{-1} \mathrm{~h}^{-1}$ year $^{-1}$ ).

The soil erosion provoked by this unique heavy rainfall event in relation to the total annual rate for MSS, MLS, LEC, SVC, NLS, NSS, and CT reached up to $98 \%, 98 \%$, $74 \%, 95 \%, 98 \%, 91 \%$, and $96 \%$, respectively. Figure $2 \mathrm{c}$ displays the soil erosion response to soil management strategies under this extreme rainfall event. According to the findings, the LEC strategy produced the lowest rate at $0.86 \mathrm{t} \mathrm{ha}^{-1}$ compared with conventional tillage with $11.8 \mathrm{tha}^{-1}$. The effectiveness of LEC in controlling water erosion was $93 \%$, whereas the NSS strategy was $84 \%$, compared with a conventional system. In general, the water erosion reduction of the agricultural system followed this pattern: organic $>$ integrated (except NLS) $>$ conservation $>$ conventional. With a slow rate of soil formation, any soil loss more than $1.0 \mathrm{tha}^{-1}$ year $^{-1}$ can be considered irreversible within a time span of $50-100$ years. Morgan (1995) revealed that losses of 20-40 tha ${ }^{-1}$ in single storms, which may occur once every 2 or 3 years, are recorded regularly in Europe, with losses of more than $100 \mathrm{t} \mathrm{ha}^{-1}$ in extreme events. As stated above, most annual soil losses are due to these types of heavy rainfall events. In addition, Ramos and Martínez (2009) estimated that the one or two events of high-intensity rainfall recorded per year generated about $75 \%$ of the total annual erosion. In this context, erosion rates higher than $10.0 \mathrm{t} \mathrm{ha}^{-1}$ were reported by Ramos and Martínez (2015) for a single event.

For surface runoff, SVC produced the lowest value (1.86 $\mathrm{mm})$ compared with a conventional tillage $(37.2 \mathrm{~mm})$ strategy (Fig. 2d). Therefore, SVC's effectiveness in trapping runoff was $95 \%$ under a heavy rainfall event, and the production systems' ability to control runoff followed the order of organic $>$ conservation $>$ integrated $>$ conventional. The results demonstrate that the ground covering vegetation absorbs rainwater energy, thus protecting the soil surface from aggregate disruption, crusting, and water erosion, and facilitating a decrease in soil compaction. Similarly, Yu et al. (2016) stated that cover crops with leguminous species produce the highest increase in soil hydraulic conductivity in the saturated/near saturated range, with coarse root axes and high rooting density more effectively reducing surface runoff. Specifically, the thick and dense network of cover crop roots (leguminous and spontaneous vegetation) in SVC (1.86 mm), as well as in MLS, LEC, and MSS (averaging $10.1 \mathrm{~mm}$ ), was able to unite the soil particles, presumably through the hyphae with some cementing agents, such as root exudates and the excretions of soil micro-organisms. The plant residues on the soil surface provided effective ground cover against heavy rainstorms, which are absent in the conventional system, as corroborated in this study by the heavy rainfall episode.

\subsection{Soil health restoration response to soil- management strategies}

\subsubsection{Physico-biochemical parameters}

Table 2 presents the average values of soil physico-chemical parameters after 3 years of experimentation. Soil macroporosity showed an increasing trend under the influence of plant cover, especially under the organic system, averaging $13.2 \%$ in relation to conventional practices $(10.1 \%)$. This finding suggested that the increase in root biomass produced improvements in soil porosity, which was strongly influenced by fine roots. Specifically, soil macroporosity is highly related to aeration, water dynamics, and the compaction of agricultural soils, which are linked to soil management. For most soils, a macroporosity of $10 \%\left(0.10 \mathrm{~m}^{3} \mathrm{~m}^{-3}\right)$ can be considered the critical limit for soil aeration, as revealed by Hakansson and Lipiec (2000). Similarly, Palese et al. (2014), under a no-tillage scenario with spontaneous vegetation cover, determined that the soil macroporosity was about $10 \%$. In contrast, under the conventional tillage in the present study, the occurrence of soil crusting and compacted layers along the profile hindered the infiltration and percolation of rainfall water, which is in line with the fixed runoff rates.

Under the experimental conditions, the soil $\mathrm{pH}$ was not affected by soil management strategies. In a 3-year study, Roldán et al. (2005) also found no changes in soil pH compared with no-tillage and conventional tillage systems.

The bulk density in almost all strategies showed an increasing trend after three seasons, particularly in organic and conservation systems. Tillage promoted the disintegration of soil aggregates and determined the formation of surface crusts, which was closely linked to the development of water erosion process. This negative impact on soils, according to our findings, was less significant than that under conservation tillage. Based on the results of the bulk density (Table 2), three categories can be discerned after 3 years: organic and conservation systems with values higher than $1.24 \mathrm{~g} \mathrm{~cm}^{-3}$, the integrated system (higher than $1.19 \mathrm{~g} \mathrm{~cm}^{-3}$ ), and the conventional system 
Table 2 Soil physico-chemical parameters $(0-0.20 \mathrm{~m}$ depth) during the three year monitoring period for each soil-management strategy and production system

\begin{tabular}{|c|c|c|c|c|c|c|c|c|c|c|}
\hline $\begin{array}{l}\text { Production } \\
\text { system }\end{array}$ & $\begin{array}{l}\text { Soil management } \\
\text { strategy }\end{array}$ & Year & $\begin{array}{l}\text { Macroporosity } \\
(\%)\end{array}$ & $\begin{array}{l}\mathrm{pH} \\
\left(\mathrm{H}_{2} \mathrm{O}\right)\end{array}$ & $\begin{array}{l}\mathrm{BD} \\
\left(\mathrm{g} \mathrm{cm}^{-3}\right)\end{array}$ & $\begin{array}{l}\mathrm{SOC} \\
\left(\mathrm{g} \mathrm{kg}^{-1}\right)\end{array}$ & $\mathrm{N}_{\mathrm{T}}$ & $\begin{array}{l}\mathrm{P} \\
\left(\mathrm{mg} \mathrm{kg}^{-1}\right)\end{array}$ & $\mathrm{K}$ & $\begin{array}{l}\text { CEC } \\
\left(\mathrm{cmol}(+) \mathrm{kg}^{-1}\right)\end{array}$ \\
\hline \multirow[t]{4}{*}{ Organic } & \multirow[t]{2}{*}{ SVC } & 2016 & $12.2 \pm 4.0$ & $7.2 \pm 0.3$ & $1.20 \pm 0.05$ & $8.8 \pm 3.2$ & $0.51 \pm 0.03$ & $4.3 \pm 2.5$ & $60.7 \pm 18$ & $14.3 \pm 5.2$ \\
\hline & & 2018 & $13.5 \pm 3.3$ & $7.5 \pm 0.2$ & $1.29 \pm 0.08$ & $10.6 \pm 4.1$ & $0.79 \pm 0.04$ & $5.5 \pm 3.8$ & $67.7 \pm 22$ & $17.9 \pm 3.4$ \\
\hline & \multirow[t]{2}{*}{ LEC } & 2016 & $11.8 \pm 2.5$ & $7.5 \pm 0.2$ & $1.19 \pm 0.06$ & $7.8 \pm 2.2$ & $0.65 \pm 0.07$ & $5.8 \pm 2.4$ & $58.8 \pm 14$ & $11.4 \pm 3.6$ \\
\hline & & 2018 & $12.9 \pm 4.2$ & $7.7 \pm 0.2$ & $1.30 \pm 0.07$ & $11.8 \pm 3.4$ & $0.88 \pm 0.05$ & $6.3 \pm 2.8$ & $74.8 \pm 17$ & $16.8 \pm 3.1$ \\
\hline \multirow[t]{4}{*}{ Conservation } & \multirow[t]{2}{*}{ MSS } & 2016 & $11.4 \pm 4.3$ & $7.5 \pm 0.1$ & $1.17 \pm 0.04$ & $8.4 \pm 4.8$ & $0.45 \pm 0.03$ & $6.4 \pm 2.6$ & $68.7 \pm 18$ & $15.8 \pm 3.0$ \\
\hline & & 2018 & $12.6 \pm 3.6$ & $7.6 \pm 0.2$ & $1.24 \pm 0.08$ & $10.2 \pm 7.5$ & $0.68 \pm 0.05$ & $7.0 \pm 3.5$ & $77.7 \pm 26$ & $16.7 \pm 7.8$ \\
\hline & \multirow[t]{2}{*}{ MLS } & 2016 & $10.0 \pm 3.4$ & $7.5 \pm 0.2$ & $1.18 \pm 0.14$ & $8.0 \pm 5.7$ & $0.58 \pm 0.01$ & $4.6 \pm 1.7$ & $84.4 \pm 14$ & $10.2 \pm 4.4$ \\
\hline & & 2018 & $11.3 \pm 3.2$ & $7.7 \pm 0.5$ & $1.26 \pm 0.07$ & $8.9 \pm 3.4$ & $0.67 \pm 0.08$ & $5.2 \pm 4.2$ & $94.7 \pm 22$ & $14.7 \pm 7.1$ \\
\hline \multirow[t]{4}{*}{ Integrated } & \multirow[t]{2}{*}{ NSS } & 2016 & $11.3 \pm 3.8$ & $7.7 \pm 0.2$ & $1.21 \pm 0.05$ & $9.5 \pm 3.8$ & $0.63 \pm 0.05$ & $5.8 \pm 4.2$ & $55.7 \pm 21$ & $8.2 \pm 3.6$ \\
\hline & & 2018 & $12.7 \pm 3.4$ & $7.4 \pm 0.3$ & $1.26 \pm 0.09$ & $10.5 \pm 5.5$ & $0.72 \pm 0.09$ & $6.8 \pm 5.4$ & $61.4 \pm 17$ & $13.8 \pm 5.8$ \\
\hline & \multirow[t]{2}{*}{ NLS } & 2016 & $12.4 \pm 2.4$ & $7.6 \pm 0.5$ & $1.20 \pm 0.06$ & $10.0 \pm 5.8$ & $0.60 \pm 0.03$ & $6.2 \pm 3.8$ & $78.5 \pm 29$ & $9.9 \pm 2.3$ \\
\hline & & 2018 & $12.7 \pm 4.9$ & $7.3 \pm 0.4$ & $1.19 \pm 0.10$ & $11.7 \pm 8.2$ & $0.78 \pm 0.05$ & $6.9 \pm 4.4$ & $83.4 \pm 21$ & $12.2 \pm 4.4$ \\
\hline \multirow[t]{2}{*}{ Conventional } & \multirow[t]{2}{*}{$\mathrm{CT}$} & 2016 & $11.7 \pm 2.8$ & $7.5 \pm 0.1$ & $1.20 \pm 0.09$ & $8.3 \pm 3.4$ & $0.55 \pm 0.03$ & $6.9 \pm 3.9$ & $67.5 \pm 18$ & $11.8 \pm 3.5$ \\
\hline & & 2018 & $10.1 \pm 3.1$ & $7.6 \pm 0.2$ & $1.10 \pm 0.15$ & $7.2 \pm 2.7$ & $0.48 \pm 0.05$ & $7.2 \pm 2.7$ & $63.7 \pm 26$ & $12.7 \pm 7.4$ \\
\hline
\end{tabular}

$B D$, bulk density; $S O C$, soil organic carbon; $N_{T}$, total nitrogen; $P$, Olsen's extractable phosphorus; $K$, available potassium; $C E C$, cation exchange capacity; $S V C$, no-tillage and spontaneous vegetation cover for the entire soil surface; $L E C$, no-tillage and legume cover for the entire soil surface; $M S S$, minimum tillage with spontaneous vegetation strips; $M L S$, minimum tillage with legume strips; NSS, no-tillage with spontaneous vegetation strips; $N L S$, no-tillage with legume strips; $C T$, conventional tillage without plant covers. \pm Standard deviation

$\left(1.10 \mathrm{~g} \mathrm{~cm}^{-3}\right)$. In other words, conventional tillage resulted in a gradual decrease in the bulk density and a worse interconnection of the soil pores due to its sealing. Tillage breaks root tubes and provokes a low structural stability of soil aggregates caused by the organic matter loss.

Regarding the soil organic carbon (SOC) content for all production systems, except for the conventional system, an increasing trend was found, which was more noticeable in the organic and conservation systems. Comparably, N, P, $\mathrm{K}$, and the cation-exchange capacity parameters increased from their previous values at the beginning of the monitoring period due to the effect of cover crops (organic), minimum tillage (conservation), and no-tillage (integrated). Strips of spontaneous vegetation and leguminous plants in the conservation and integrated systems have the potential to fix and supply the plant nutrients required for their own growth, as well as transfer those nutrients to olive trees in intercropping systems. This is in line with the findings of Ferreira et al. (2013), who reported that the SOC and available $\mathrm{N}$ and $\mathrm{P}$ were higher in soils covered with spontaneous vegetation in rainfed olive orchards (grazed pasture) compared with conventional tillage. Studies examining a large range of crops, soil types, and environmental conditions reported that no-tillage and minimum tillage systems effectively increased SOC storage and promoted more favorable conditions in the upper soil layers than conventional tillage, as revealed by Madejón et al. (2009).
In our experiment, leguminous plants exerted a key impact on available soil $\mathrm{K}$ in all studied strategies compared with conventional systems. Similar results were found in a study where the extensive root systems of legumes were proven to help them release organic acids from their roots, which increased available K in soil (Sujatha et al. 2017).

Finally, in this study, the effects of temporary cover crops (spontaneous and legume plants) on soil properties yielded notable improvements in physico-chemical parameters (e.g., bulk density, soil-organic carbon, total nitrogen, and potassium) compared with conventional tilled soils. This supports the positive impact of this measure on the key soil variables regulating the provision of ecosystem services in the medium and long term. Thus, the sensitivity of the physico-chemical soil indicators that were examined with regard to the modifications caused by different soil management strategies demonstrated that the soil subjected to conventional tillage had poorer soil conditions.

\subsubsection{Microbial biomass and soil enzymatic activities}

Table 3 shows the impact of soil management strategies in each production system on the soil microbial biomass and enzymatic activities throughout the study period. In general, the ranking from highest to lowest in terms of soil microbial and enzyme activity was organic $>$ conservation $>$ integrated $>$ conventional system. The evidence for the effect of the cover crops and herbicides on soil microbiological and 
Table 3 Soil microbial and enzymatic activities ( $0-0.20 \mathrm{~m}$ depth) during the monitoring period for each soil management strategy and production system

\begin{tabular}{|c|c|c|c|c|c|c|c|c|}
\hline $\begin{array}{l}\text { Production } \\
\text { system }\end{array}$ & $\begin{array}{l}\text { Soil management } \\
\text { strategy }\end{array}$ & Year & $\begin{array}{l}\mathrm{MB}_{\mathrm{N}} \\
\left(\mathrm{mg} \mathrm{kg}^{-1}\right)\end{array}$ & $\mathrm{MB}_{\mathrm{C}}$ & $\begin{array}{l}\beta \text {-GLU } \\
\left(\mu \mathrm{g} p \mathrm{NP} \mathrm{g}^{-1} \mathrm{~h}^{-1}\right)\end{array}$ & $\begin{array}{l}\text { PRO } \\
\left(\mu \mathrm{g} \text { TRS } g^{-1} h^{-1}\right)\end{array}$ & $\begin{array}{l}\text { DHA } \\
\left(\mu \mathrm{g} \mathrm{TPF} \mathrm{g}^{-1} \mathrm{~h}^{-1}\right)\end{array}$ & $\begin{array}{l}\text { PHP } \\
\left(\mu \mathrm{g} p \mathrm{NP} \mathrm{g}^{-1} \mathrm{~h}^{-1}\right)\end{array}$ \\
\hline \multirow[t]{4}{*}{ Organic } & \multirow[t]{2}{*}{ SVC } & 2016 & $5.1 \pm 0.8$ & $3.7 \pm 0.78$ & $370 \pm 0.9$ & $12.8 \pm 0.9$ & $103.2 \pm 7.7$ & $133.7 \pm 10.7$ \\
\hline & & 2018 & $6.8 \pm 1.2$ & $4.2 \pm 0.86$ & $441 \pm 0.7$ & $13.1 \pm 0.8$ & $122.7 \pm 6.5$ & $145.0 \pm 15.9$ \\
\hline & \multirow[t]{2}{*}{ LEC } & 2016 & $6.4 \pm 0.9$ & $3.4 \pm 1.30$ & $311 \pm 1.2$ & $13.0 \pm 0.9$ & $101.1 \pm 8.2$ & $142.0 \pm 11.2$ \\
\hline & & 2018 & $7.9 \pm 1.2$ & $4.1 \pm 0.97$ & $472 \pm 0.9$ & $13.6 \pm 1.2$ & $113.4 \pm 5.9$ & $159.5 \pm 18.7$ \\
\hline \multirow[t]{4}{*}{ Conservation } & \multirow[t]{2}{*}{ MSS } & 2016 & $5.8 \pm 2.2$ & $3.4 \pm 1.35$ & $401 \pm 1.2$ & $12.0 \pm 1.4$ & $99.20 \pm 1.9$ & $131.5 \pm 11.8$ \\
\hline & & 2018 & $6.9 \pm 3.4$ & $3.8 \pm 1.08$ & $452 \pm 2.4$ & $12.8 \pm 1.5$ & $111.8 \pm 3.4$ & $139.8 \pm 22.4$ \\
\hline & \multirow[t]{2}{*}{ MLS } & 2016 & $5.0 \pm 1.2$ & $3.1 \pm 0.97$ & $461 \pm 1.9$ & $11.9 \pm 0.9$ & $100.7 \pm 2.7$ & $120.4 \pm 17.1$ \\
\hline & & 2018 & $6.4 \pm 0.9$ & $4.2 \pm 2.43$ & $483 \pm 3.5$ & $12.7 \pm 1.6$ & $119.1 \pm 5.2$ & $131.4 \pm 13.7$ \\
\hline \multirow[t]{4}{*}{ Integrated } & \multirow[t]{2}{*}{ NSS } & 2016 & $5.7 \pm 2.1$ & $2.5 \pm 1.81$ & $282 \pm 1.8$ & $12.5 \pm 1.1$ & $97.45 \pm 8.8$ & $132.3 \pm 22.8$ \\
\hline & & 2018 & $6.7 \pm 3.7$ & $2.9 \pm 1.28$ & $232 \pm 2.5$ & $12.8 \pm 2.2$ & $110.8 \pm 5.9$ & $138.6 \pm 43.1$ \\
\hline & \multirow[t]{2}{*}{ NLS } & 2016 & $5.2 \pm 2.2$ & $2.1 \pm 1.25$ & $231 \pm 1.9$ & $11.9 \pm 2.1$ & $96.48 \pm 7.5$ & $133.9 \pm 25.2$ \\
\hline & & 2018 & $5.4 \pm 3.5$ & $2.7 \pm 1.41$ & $242 \pm 2.7$ & $12.5 \pm 1.9$ & $103.2 \pm 8.7$ & $140.4 \pm 13.2$ \\
\hline \multirow[t]{2}{*}{ Conventional } & \multirow[t]{2}{*}{$\mathrm{CT}$} & 2016 & $5.3 \pm 0.8$ & $2.0 \pm 0.78$ & $131 \pm 1.2$ & $11.7 \pm 1.4$ & $92.43 \pm 5.1$ & $122.0 \pm 21.5$ \\
\hline & & 2018 & $4.3 \pm 0.7$ & $1.3 \pm 0.94$ & $196 \pm 1.8$ & $12.4 \pm 1.9$ & $92.78 \pm 4.9$ & $129.6 \pm 20.9$ \\
\hline
\end{tabular}

$\beta$-GLU, $\beta$-glucosidase; $P R O$, protease; $D H A$, dehydrogenase; $P H P$, phosphatase; $M B_{N}$, microbial biomass-nitrogen; $M B_{C}$, microbial biomass-carbon; $S V C$, no-tillage and spontaneous vegetation cover for the entire soil surface; $L E C$, no-tillage and legume cover for the entire soil surface; $M S S$, minimum tillage with spontaneous vegetation strips; $M L S$, minimum tillage with legume strips; NSS, no-tillage with spontaneous vegetation strips; $N L S$, no-tillage with legume strips; $C T$, conventional tillage without plant covers. \pm Standard deviation

enzyme activity was widespread (conventional and integrated systems). This contrasts with the use of cover crops and mechanical control of weeds (organic and conservation agriculture systems). Soil microbial biomass $\left(\mathrm{MB}_{\mathrm{C}}\right.$ and $\left.\mathrm{MB}_{\mathrm{N}}\right)$ is the main force driving the decomposition of organic matter and is regularly used as an early indicator of changes in soil parameters resulting from soil management systems, as corroborated by the findings of the present experiment. The LEC strategy was more effective than SVC since the former provided larger quantities of $\mathrm{N}$ and lower $\mathrm{C}: \mathrm{N}$ ratios than the latter. In this way, the roots from cover crops stimulated the enzyme activity by either releasing enzymes or sustaining higher microbial activity in the rhizosphere.

The conventional system demonstrated that the mineralization rate increased and that a part of the organic matter was presumably lost to the environment, thus lessening the soil enzymatic activities compared with the remaining systems, which agrees with Zuber and Villamil (2016) compared with the non-integrated system with minimum tillage (conservation agriculture system). This is in line with Kandeler et al. (1999), who noted that protease and phosphatase activities significantly increased after only 2 years of minimum tillage compared with conventional tillage. Roldán et al. (2003) highlighted that soil no-till and legume cover significantly improved the soil enzyme activities (dehydrogenase, urease, protease, $\beta$-glucosidase, and acid phosphatase), which agrees with the integrated systems (particularly NLS) in this study. The use of an integrated no-tillage system following herbicide application lowered the dehydrogenase activity compared with organic and conservation systems. This was also reported by Benitez et al. (2006) for olive orchards.

As argued previously, plant cover strips with their root systems are able to encourage the development of porosity and infiltration, thus enabling the root zone to act as a partial sink for surface runoff. This triggers an increase in the soilwater content that strongly influences the soil's microbial activity, community composition, and, consequently, enzymatic activities (Geisseler et al. 2011). This differs from a conventional system, where, as soils dry, the water potential decreases, and microbial activity decreases as intracellular enzyme activity slows.

In our study, the no-till system (NSS and NLS) produced an increase in the activities of $\beta$-glucosidase and $\mathrm{MB}_{\mathrm{C}}$ and $\mathrm{MB}_{\mathrm{N}}$ in contrast to conventional system. Sinsabaugh et al. (2008) reported that minimum tillage encourages and increases $\beta$-glucosidase activity due to enhanced microbial biomass, greater substrate availability, and reduced soil disturbance, as found in conservation agriculture compared with the conventional system. According to Benitez et al. (2016), conventional tillage increased $C$ mineralization and reduced the activity of $\beta$ glucosidase in a long-term study with rainfed olive orchards, noting that this enzyme could be an adequate indicator of the sustainability of agricultural management systems. In organically managed soils, the activity of $\beta$ glucosidase increased as this enzyme is responsible for catalyzing the degradation of cellulose from plant covers (Veum et al. 2014). This was most evident in the organic 
system (LEC and SVC) but less intense in the remaining soil treatments with cover crop strips, with the vegetation restoration in the hillslope soils provoking this increasing trend. In this study, both protease and $\beta$-glucosidase augmented their activities by affecting the cover crops, particularly in the organic system with legume plants.

According to the findings of the present experiment, an increasing trend for phosphatase activity was observed in the organic system with leguminous roots (LEC) and, to a lesser degree, in conservation agriculture (MLS) and integrated (NLS) systems, thus increasing the available P. In this sense, Makoi et al. (2010) highlighted that leguminous plants release more phosphatase enzymes than non-leguminous plants. This occurs because leguminous plants (Rhizobium) demand more $\mathrm{P}$ in the symbiotic $\mathrm{N}$ fixation process than cereal plants, as outlined by Makoi and Ndakidemi (2008). Therefore, in this experiment, higher phosphatase activity was registered under integrated (no-till) and conservation (minimum tillage) systems compared with the conventional tillage system. This fact suggested that phosphatase activity promptly produced changes in soil organic matter caused by tillage. Specifically, tillage should be reduced to increase the biological activity of soils to improve $\mathrm{P}$ nutrient cycling processes and soil structure.

The soils under a conventional system had lower dehydrogenase activity compared with the organic and conservation systems, presumably due to the agrochemical inputs that could have reduced the biological activity in line with the findings reported by Benitez et al. (2006). Similarly, Nivelle et al. (2016) reported differences in dehydrogenase levels due to tillage practices but no important alterations due to cover crop treatment. In this way, the integrated system with no-tillage increased the soils' dehydrogenase activity compared with conventional tilled soils. The differences tended to increase over the 3 years since the cover crops were planted for all enzyme activities.

In short, the production system impacted the soil microorganisms and microbial processes ascribed to changes in the quantity and quality of the plant residues that enter the soil, their spatial distribution, changes in the provision of nutrients, and physical alterations. Thus, the alternative modifications to conventional production systems, based on the methods used in organic, integrated, and conservation agriculture, tended to improve important aspects of soil health restoration.

\subsubsection{Biochemical parameters and enzymatic activity related to production systems}

Table 4 displays a pooled correlation matrix among the production systems, soil biochemical activities, and enzymatic activities. Important differences in the correlation values $(p<0.01$ ) were found for the organic system compared with the other systems. A weak or absent relationship of dehydrogenase with most biochemical soil parameters in organic, conservation, and integrated systems was found in contrast to the conventional system. The soil parameters were positively correlated with soil enzyme activities and SOC, which agrees with the findings of Veum et al. (2014). According to Adetunji et al. (2017), phosphatase is an enzyme capable of hydrolyzing organic esters and converting them into inorganic phosphate and $\beta$-glucosidase; this is closely connected to the $\mathrm{C}$-cycle that catalyzes the transformation of disaccharides into glucose. Thus, both phosphate and $\beta$-glucosidase were positively correlated with $\mathrm{P}(0.973, p<0.01)$ and SOC $(0.512, p<0.05)$, in soils under the organic system compared with the other systems, especially the conventional system. The $\mathrm{MB}_{\mathrm{C}}$ with $\beta$-glucosidase $(-0.602, p<$ 0.05 ) was negatively correlated with conventional tilled soils. These findings support the intense hydrolytic activity in organic soils that probably promotes higher nutrient availability (phosphates and carbon compounds) for microorganisms and plants. In this study, the $\beta$-glucosidase activity was positively correlated with the total nitrogen $\left(\mathrm{N}_{\mathrm{T}}\right)$ in the organic system $(0.735, p<0.05)$ and negatively with the conventional system $(-0.693, p<0.05)$.

Additionally, in organic soils, a strong relationship was found between $\mathrm{MB}_{\mathrm{C}}$ and $\mathrm{MB}_{\mathrm{N}}$ and phosphatase, which are in line with the findings of Bowles et al. (2014), who noted the importance of soil microbial biomass for regulating investments in phosphatases. A strong correlation was also determined between the $\mathrm{SOC}$ and $\mathrm{MB}_{\mathrm{C}}$ and $\mathrm{MB}_{\mathrm{N}}$ for all production systems, which agrees with Melero et al. (2007). The $\mathrm{MB}_{\mathrm{C}}$ was also closely associated with $\mathrm{MB}_{\mathrm{N}}$ for all productions systems.

On the other hand, since plants only uptake inorganic P, and a large amount of soil $\mathrm{P}$ is organically bound, the mineralization of this organic portion is essential for plant nutrition. Therefore, this factor is linked to the production and activity of soil phosphatase, which boosts the inorganic $\mathrm{P}$ availability for plants and microorganisms in rainfed olive orchards (Rodrigues et al. 2015). Our findings showed that phosphatase activity was significantly related to $\mathrm{SOC}$ and $\mathrm{MB}_{\mathrm{C}}$ in organic, integrated, and conservation agriculture systems and at a lower level in the conventional system.

Meanwhile, the protease enzyme is highly related to the $\mathrm{N}$ cycling that regulates the amount of plant available $\mathrm{N}$ (mineralization) and plant growth, as outlined by Das and Varma (2010). Thus, the relationship of protease with $\mathrm{N}_{\mathrm{T}}$ showed the following decreasing order: integrated $(0.624, p<0.05)$, conservation $(0.604, p<0.05)$, organic $(0.550, p<0.05)$, and conventional $(0.409, p<0.05)$ (Table 4).

Dehydrogenase activity is involved in C cycling, significantly accelerating the transformation of organic carbon compounds (Adetunji et al. 2017). In this sense, the relationships between SOC and $\mathrm{MB}_{\mathrm{C}}(0.957(p<0.01)$ and $0.746(p<$ 
Table 4 Pearson correlation matrix among the soil biochemical parameters and microbial activities for the production systems

\begin{tabular}{|c|c|c|c|c|c|c|c|c|c|c|c|}
\hline & $\mathrm{pH}$ & SOC & $\mathrm{N}_{\mathrm{T}}$ & $\mathrm{P}$ & K & $\mathrm{MB}_{\mathrm{C}}$ & $\mathrm{MB}_{\mathrm{N}}$ & $\beta-G L U$ & PRO & DHA & PHP \\
\hline & \multicolumn{11}{|c|}{ Organic system } \\
\hline $\mathrm{pH}$ & 1 & 0.566 & $0.708 *$ & 0.568 & 0.312 & $0.725 *$ & 0.473 & 0.363 & 0.506 & 0.115 & $0.612 *$ \\
\hline SOC & & 1 & 0.634 & $0.899 * *$ & $0.851 *$ & $0.862 *$ & $0.910 * *$ & 0.512 & $0.927 * *$ & 0.733 & $0.927 * *$ \\
\hline $\mathrm{N}_{\mathrm{T}}$ & & & 1 & 0.475 & 0.224 & $0.878 *$ & 0.503 & $0.735^{*}$ & $0.550 *$ & 0.090 & $0.753 *$ \\
\hline $\mathrm{P}$ & & & & 1 & $0.862 *$ & $0.824 *$ & $0.853 *$ & 0.117 & $0.946^{* *}$ & 0.108 & $0.973 * *$ \\
\hline K & & & & & 1 & 0.554 & $0.899 * *$ & 0.139 & $0.825 *$ & 0.025 & $0.672 *$ \\
\hline $\mathrm{MB}_{\mathrm{C}}$ & & & & & & 1 & $0.728^{*}$ & $0.507 *$ & $0.850 *$ & 0.128 & $0.966 * *$ \\
\hline $\mathrm{MB}_{\mathrm{N}}$ & & & & & & & 1 & 0.379 & $0.918^{* *}$ & 0.053 & $0.810^{* *}$ \\
\hline$\beta-G L U$ & & & & & & & & 1 & 0.268 & 0.001 & 0.446 \\
\hline PRO & & & & & & & & & 1 & 0.105 & $0.939 * *$ \\
\hline DHA & & & & & & & & & & 1 & 0.122 \\
\hline \multirow[t]{2}{*}{ PHP } & & & & & & & & & & & 1 \\
\hline & \multicolumn{11}{|c|}{ Conventional system } \\
\hline $\mathrm{pH}$ & 1 & $0.737 *$ & 0.384 & $0.836^{* *}$ & $0.878 * *$ & 0.441 & $0.652 *$ & 0.394 & $0.979 * *$ & $0.893 * *$ & $0.937 * *$ \\
\hline SOC & & 1 & $0.798 *$ & $0.956^{* *}$ & $0.950 * *$ & $0.900^{* *}$ & $0.956^{* *}$ & -0.197 & $0.851 *$ & $0.957 * *$ & $0.895 *$ \\
\hline $\mathrm{N}_{\mathrm{T}}$ & & & 1 & 0.591 & $0.766^{*}$ & $0.966^{* *}$ & $0.934 * *$ & $-0.693 *$ & $0.409^{*}$ & $0.637^{*}$ & 0.499 \\
\hline $\mathrm{P}$ & & & & 1 & $0.923 * *$ & $0.734 *$ & $0.837 *$ & 0.090 & $0.928 * *$ & $0.987 * *$ & $0.869 *$ \\
\hline $\mathrm{K}$ & & & & & 1 & $0.816^{*}$ & $0.935 * *$ & -0.070 & $0.935 * *$ & 0.968 & $0.929 * *$ \\
\hline $\mathrm{MB}_{\mathrm{C}}$ & & & & & & 1 & $0.966 * *$ & $-0.602 *$ & 0.576 & $0.746^{*}$ & $0.620 *$ \\
\hline $\mathrm{MB}_{\mathrm{N}}$ & & & & & & & 1 & -0.410 & $0.755^{*}$ & $0.870^{*}$ & $0.774 *$ \\
\hline$\beta-G L U$ & & & & & & & & 1 & 0.285 & 0.080 & 0.250 \\
\hline PRO & & & & & & & & & 1 & $0.964 * *$ & $0.986 * *$ \\
\hline DHA & & & & & & & & & & 1 & $0.985 * *$ \\
\hline \multirow[t]{2}{*}{ PHP } & & & & & & & & & & & 1 \\
\hline & \multicolumn{11}{|c|}{ Integrated system } \\
\hline $\mathrm{pH}$ & 1 & $0.686^{*}$ & 0.051 & $0.758^{*}$ & $0.601 *$ & $0.768 *$ & $0.704 *$ & 0.352 & $0.800^{*}$ & -0.170 & 0.059 \\
\hline SOC & & 1 & 0.577 & $0.872 *$ & $0.800 *$ & $0.842 *$ & $0.825 *$ & -0.026 & $0.864 *$ & 0.285 & 0.521 \\
\hline $\mathrm{N}_{\mathrm{T}}$ & & & 1 & $0.626^{*}$ & 0.540 & 0.584 & $0.654 *$ & -0.170 & $0.624 *$ & $0.751^{*}$ & $0.927 * *$ \\
\hline$P$ & & & & 1 & $0.830 *$ & $0.962 * *$ & $0.957 * *$ & 0.001 & $0.962 * *$ & 0.315 & 0.514 \\
\hline $\mathrm{K}$ & & & & & 1 & $0.678 *$ & $0.751 *$ & -0.247 & $0.756^{*}$ & 0.151 & 0.568 \\
\hline $\mathrm{MB}_{\mathrm{C}}$ & & & & & & 1 & $0.930^{* *}$ & 0.059 & $0.966^{* *}$ & 0.387 & 0.461 \\
\hline $\mathrm{MB}_{\mathrm{N}}$ & & & & & & & 1 & 0.076 & $0.927 * *$ & 0.412 & 0.528 \\
\hline$\beta-G L U$ & & & & & & & & 1 & 0.107 & -0.421 & -0.477 \\
\hline PRO & & & & & & & & & 1 & 0.371 & 0.513 \\
\hline DHA & & & & & & & & & & 1 & $0.826^{*}$ \\
\hline \multirow[t]{2}{*}{ PHP } & & & & & & & & & & & 1 \\
\hline & \multicolumn{11}{|c|}{ Conservation system } \\
\hline $\mathrm{pH}$ & 1 & $0.721 *$ & 0.591 & $0.821 *$ & $0.800 *$ & $0.638^{*}$ & $0.962 * *$ & 0.291 & $0.881 *$ & $0.613 *$ & $0.754 *$ \\
\hline SOC & & 1 & 0.409 & $0.874 *$ & $0.790 *$ & $0.936 * *$ & $0.795 *$ & 0.086 & $0.917 * *$ & 0.381 & $0.944 * *$ \\
\hline $\mathrm{N}_{\mathrm{T}}$ & & & 1 & 0.354 & $0.620 *$ & 0.474 & 0.548 & $0.813^{* *}$ & $0.604 *$ & $0.853 *$ & 0.435 \\
\hline $\mathrm{P}$ & & & & 1 & $0.652 *$ & $0.843 *$ & $0.890 * *$ & -0.122 & $0.924 * *$ & 0.318 & $0.917 * *$ \\
\hline $\mathrm{K}$ & & & & & 1 & $0.714 *$ & $0.810 *$ & 0.539 & $0.840 *$ & 0.547 & $0.645^{*}$ \\
\hline $\mathrm{MB}_{\mathrm{C}}$ & & & & & & 1 & $0.744 *$ & 0.107 & $0.903 * *$ & 0.496 & $0.933 * *$ \\
\hline $\mathrm{MB}_{\mathrm{N}}$ & & & & & & & 1 & 0.211 & $0.950 * *$ & 0.582 & $0.815^{*}$ \\
\hline$\beta-G L U$ & & & & & & & & 1 & 0.229 & $0.714^{*}$ & -0.006 \\
\hline PRO & & & & & & & & & 1 & 0.586 & $0.916^{* *}$ \\
\hline DHA & & & & & & & & & & 1 & 0.479 \\
\hline PHP & & & & & & & & & & & 1 \\
\hline
\end{tabular}

$S O C$, soil organic carbon; $N_{T}$, total nitrogen; $P$, Olsen's extractable phosphorus; $K$, available potassium; $\beta$ - $G L U$, $\beta$-glucosidase; $P R O$, protease; $D H A$, dehydrogenase; $P H P$, phosphatase; $M B_{C}$, microbial biomass-carbon; $M B_{N}$, microbial biomass-nitrogen. * and ** significant at $p<0.05$ and $p<0.01$, respectively

0.05), respectively) in conventional soil were much stronger than those in the other systems. This could explain the growth of microbial biomass, which is associated with the dehydrogenase enzyme (Zhang et al. 2010). In this study, dehydrogenase and protease were positively correlated $(0.964, p<0.01)$ in the conventional system in contrast to the organic, integrated, and conservation systems. Similar results were presented by Melero et al. (2007).
Finally, soil enzymes catalyze and encourage decomposition and plant nutrient cycling, so their activities are a biological sign of improving soil quality. Soil enzymes respond to soil management changes long before other soil quality alterations are detectable. Their activities may be affected by physical and chemical soil properties, as well as soil management regimes. Overall, the implementation of intercropping (legume or spontaneous), conservation tillage (minimum tillage/no-tillage), and organically managed soils led to 
improvements in soil quality and protected the soil against water erosion.

\subsection{Olive yield}

The average olive yields per area in terms of the soil management strategies over the entire study period for MSS, MLS, LEC, SVC, NLS, NSS, and CT were 2.15, 1.92, 2.21, 2.00, $2.43,2.42$, and $2.19 \mathrm{t} \mathrm{ha}^{-1}$, respectively, with an average disparity of $506.0 \mathrm{~kg} \mathrm{ha}^{-1}$ between the most and least productive strategies (NLS vs. MLS, respectively). The average olive production values, which were not significantly different during the four seasons under the integrated, organic, conservation, and conventional production systems, were 2.43, 2.10, 2.04, and $2.11 \mathrm{t} \mathrm{ha}^{-1}$ year ${ }^{-1}$, respectively. Soriano et al. (2014) similarly reported that rainfed organic olives achieved similar productivity (2.90 $\mathrm{t} \mathrm{ha}^{-1}$ year $\left.^{-1}\right)$ to the conventionally grown olives without significant differences due to the soil management type used. In addition, Simoes et al. (2014) reported that the olive yield was not affected by the soil management system, which contradicts Ferraj et al. (2011), who found improvements in olive productivity with an organic system compared with a conventional system.

The accumulated olive yields for each production system (average weighted for soil management strategies) during the study period are shown in Fig. 3a. At the end of the fourmonitoring seasons, the maximum was $9.7 \mathrm{t} \mathrm{ha}^{-1}$ with the integrated system followed by the conventional, organic, and conservation systems, with values of $8.8,8.4$, and $8.1 \mathrm{t} \mathrm{ha}^{-1}$, respectively. Therefore, the most consistent strategy for productivity seems to be the integrated system with rational agricultural inputs, with the use of strips of cover crops as a sustainable tool for soil protection and rainwater harvesting.

The alternate yield of olive trees, as claimed by Lavee et al. (2012), had an important impact on annual fruit yield, particularly in 2016 (Fig. 3b). The annual rainfall amount during the first $(320.0 \mathrm{~mm})$ and fourth $(357.2 \mathrm{~mm})$ seasons likely promoted the increasing trend in olive yield. A wide variability in yield - with important differences between years - is typical for rainfed olives, as demonstrated by Sola et al. (2017). In this study, the average olive yields for all experimental plots in $2015,2016,2017$, and 2018 were $17.3,5.5,15.0$, and $18.7 \mathrm{~kg}$ tree ${ }^{-1}$, respectively. In this context, according to Tubeileh et al. (2014), for rainfed plantations, the olive yield varied considerably from 6.0 to $65.0 \mathrm{~kg}$ tree $^{-1}$.

These findings for productivity suggest that conventional rainfed olive orchards that yield at a similar production level should consider shifting to soil management systems based on organic, integrated, or conservation techniques, particularly integrated systems, without incurring important yield losses.

\subsubsection{Toward the sustainable development of rainfed hillslope farming}

Agricultural production systems are intensive by nature and present considerable concerns for soil degradation and crop resiliency, particularly under changing climate conditions. The environmental sustainability of particular soil management strategies can only be appraised using an exhaustive approach to quantify their impact on soil functions. Under our experimental conditions, we found that organic, conservation, and integrated systems with minimum tillage, no-tillage, and cover crops, as well as a combination of these techniques, induced different positive responses compared with the conventional system. The olive yield was practically unaffected by the soil management strategy applied. Equilibrium between soil protection and yield was thus partially achieved. Unlike productivity, different soil management strategies, with the exception of the conventional tillage, had marked effects on the soil's physical, chemical, and biological parameters.

At present, there is a demand for a holistic consideration of soil conservation and multidisciplinary soil management approaches that integrate biological, chemical, and physical strategies to obtain soils that can support sustainable agriculture. Current conventional practices lower soil biodiversity,

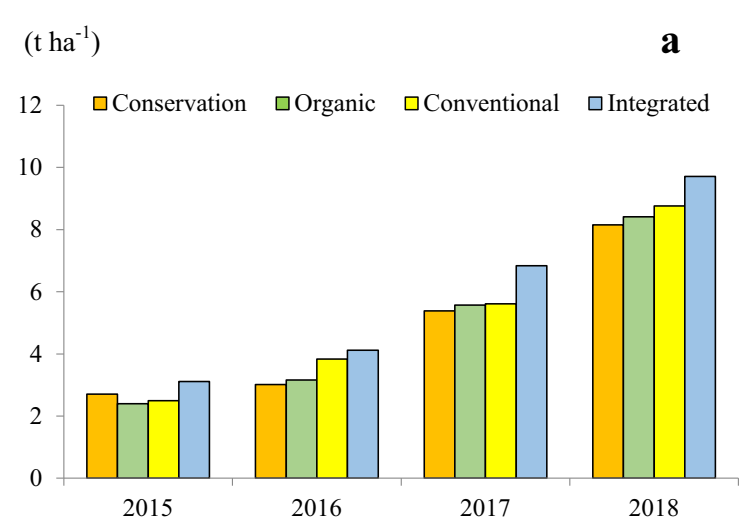

$\left(\mathrm{kg}\right.$ tree $\left.^{-1}\right)$

b

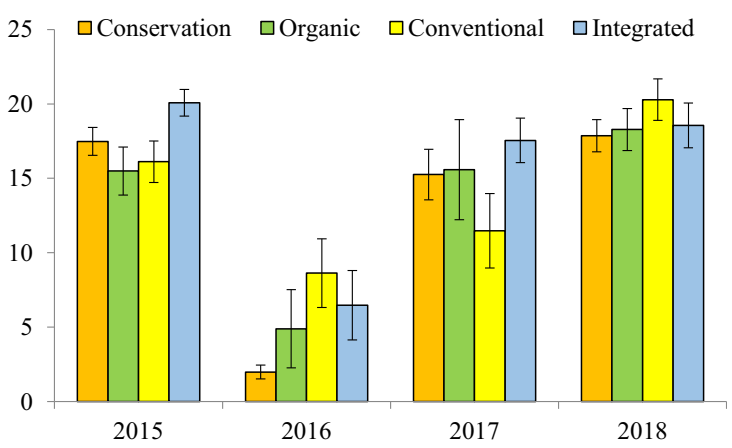

Fig. 3 Accumulative olive yield (A) and average annual fruit yield (B) in relation to the agricultural system production during the four monitoring seasons. Vertical bars indicate standard deviation 
mainly due to the overuse of chemical inputs, leading to compaction or water erosion and hence irreversible adverse alterations, resulting in a loss of agricultural productivity as was corroborated by the results of the present experiment. That is, the implementation of organic management is an attractive option for improving soil health. However, this method has significant risks of yield reductions due to the restriction of external inputs. Therefore, instead of persisting in the competition between organic and conventional systems, an alternative management option that includes pro and contra perspectives could be more appropriate - that is, using soil amendments, cover cropping, no-tillage, and reduced tillage practices similar to organic or conservation agriculture but without enforcing external input limitations in rational terms. According to our findings, and after considering the equilibrium between environmental and agronomical benefits, we suggest that integrated systems are most appropriate for rainfed olive orchards. In this context, Stavi et al. (2016) reported that the agro-environmental scores of soil functions and ecosystem services were the highest for conservation, intermediate for integrated, and the lowest for conventional systems. The productivity score was the largest for integrated, intermediate for conventional, and the smallest for conservation systems. These observations support our argument based on the findings of the present experiment.

\section{Conclusions}

Clear differences in runoff, soil loss, and soil health restoration indicators were found throughout the monitoring seasons as a result of the interplay between soil management strategies for each investigated production system. The findings illustrate the potential environmental benefits of the organic system in controlling soil erosion and runoff and improving soil health restoration compared with a conventional system. The conservation agriculture and integrated systems occupy an intermediate position between these two extremes. In addition, the data showed that by taking advantage of water erosion control and the enhancement of soil health by organic, integrated, and conservation agriculture compared with a conventional system, the olive yield was not significantly affected. The implementation of practices related to the organic system positively contributes to the multifunctionality and sustainability of olive plantations. However, a fusion between organic and conventional systems seems to be a more compelling approach to conserve or enhance soil health indices while maintaining yields, rather than strictly using organic management. Therefore, to achieve a balance between environmental and agronomical interests, integrated systems are more suitable for rainfed olive orchards.
Ultimately, agricultural development is currently facing unprecedented challenges. Here, we show that the sustainable intensification of agriculture will play a significant role in facing these challenges, relying on the integrated use of a wide range of strategies to manage soil. Thus, this integrated perspective is particularly urgent in traditional olive-producing areas, where orchards cover vast tracts of land.

\section{Compliance with ethical standards}

Funding This publication was sponsored by the following research project "Agro-environmental assessment of conventional, integrated, conservation and organic olive production systems in mountainous areas: impact on erosion, soil quality and commercial value of olive oil" (P11 AGR-7431) granted by CEICE of Junta de Andalucía and "Impact of climate change and adaptation measures (INNOVA-Climate)" (AVA.AVA2019.051), co-financed by the European Regional Development Fund (ERDF), Research Projects and Technological Innovation for 2019-2021.

Conflict of interest The authors declare that they have no conflict of interest.

Author's contribution All authors contributed equally toward the research and the writing of the paper.

\section{References}

Adetunji AT, Lewu FB, Mulidzi R, Ncube B (2017) The biological activities of $\beta$-glucosidase, phosphatase and urease as soil quality indicators: a review. J Soil Sci Plant Nutr 17:794-807. https://doi. org/10.4067/S0718-95162017000300018

Arampatzis G, Hatzigiannakis E, Pisinaras V, Kourgialas N, Psarras G, Kinigopoulou V, Panagopoulos A, Koubouris G (2018) Soil water content and olive tree yield responses to soil management, irrigation, and precipitation in a hilly Mediterranean area. J Water Clim Change 9:672-678. https://doi.org/10.2166/wcc.2018.224

Beaufoy G (2001) The environmental impact of olive oil production in the European Union: practical options for improving the environmental impact. https://ec.europa.eu/environment/agriculture/pdf/ oliveoil.pdf Accessed 5 January 2020

Benitez E, Nogales R, Campos M, Ruano F (2006) Biochemical variability of olive-orchard soils under different management systems. Appl Soil Ecol 32:221-231. https://doi.org/10.1016/j.apsoil.2005.06.002

Benitez E, Nogales R, Doni S, Masciandaro G, Moreno B (2016) Biochemically active humic substances in contrasting agricultural managements. Span. J Agric Res 3:e03SC01. https://doi.org/10. 5424/sjar/2016143-8431

BOJA (2008) Boletín Oficial de La Junta de Andalucía N ${ }^{\circ} 83$. Orden de 15 de abril de 2008, por la que se aprueba el Reglamento Específico de Producción Integrada de Olivar. https://www.juntadeandalucia. es/boja/2008/83/d2.pdf. Accessed 5 January 2020

Bowles TM, Acosta MV, Calderón F, Jackson LE (2014) Soil enzyme activities, microbial communities, and carbon and nitrogen availability in organic agroecosystems across an intensively-managed agricultural landscape. Soil Biol Biochem 68:252-262. https://doi. org/10.1016/j.soilbio.2013.10.004

Casida LE, Klein DA, Santoro R (1964) Soil dehydrogenase activity. Soil Sci 98:371-376

Castellini M, Stellacci AM, Mastrangelo M, Caputo F, Manici LM (2020) Estimating the soil hydraulic functions of some olive orchards: soil 
management implications for water saving in soils of Salento peninsula (southern Italy). Agron 10(2):177. https://doi.org/10.3390/ agronomy 10020177

Das SK, Varma A (2010) Role of enzymes in maintaining soil health. In: Shukla G, Varma A (eds) Soil Enzymology, vol 22. Springer, Verlag Berlin Heidelberg. https://doi.org/10.1007/978-3-64214225-3 2

Durán ZVH, Rodríguez PCR (2008) Soil-erosion and runoff prevention by plant covers, a review. Agron Sustain Dev 28:65-86. https://doi. org/10.1051/agro:2007062

Durán ZVH, Rodríguez PCR, Arroyo PL, Martínez RA, Francia MJR, Cárceles RB (2009a) Soil conservation measures in rainfed olive orchards in south-eastern Spain: impacts of plant strips on soil water dynamics. Pedosphere 19:453-464. https://doi.org/10.1016/S10020160(09)60138-7

Durán ZVH, Pleguezuelo RCR, Flanagan CD, Francia MJR, Martínez RA (2009b) Agricultural runoff: new research and trends. In: Hudspeth CA, Reeve TE (eds) Agricultural Runoff, Coastal Engineering and Flooding. Nova Science Publishers. Hauppauge, New York, USA, pp 27-48

Efe R (2012) Olive and olive oil culture in the Mediterranean Region. In: Efe R, Öztürk M, Ghazanfar S (eds) Environment and Ecology in the Mediterranean Region, $1^{\text {st }}$ Edition, Chapter: 5. Cambridge Scholars Publishing, Newcastle, pp 54-64

ESYRCE (2019) https:/www.mapa.gob.es/es/estadistica/temas/ estadisticas-agrarias/comentariosespana2019 tcm30-522390.pdf

Ferraj B, Teqja Z, Susaj L, Fasllia N, Gjeta Z, Vata N, Balliu A (2011) Effects of different soil management practices on production and quality of olive groves in Southern Albania. J Food Agric Environ 9:430-433

Ferreira IQ, Arrobas M, Claro AM, Rodrigues MA (2013) Soil management in rainfed olive orchards may result in conflicting effects on olive production and soil fertility. Span J Agric Res 2:472-480. https://doi.org/10.5424/sjar/2013112-3501

Francia MJR, Durán ZVH, Martínez RA (2006) Environmental impact from mountainous olive orchards under different soil-management systems (SE Spain). Sci Total Environ 358:46-60. https://doi.org/ 10.1016/j.scitotenv.2005.05.036

Geisseler D, Horwath WR, Scow KM (2011) Soil moisture and plant residue addition interact in their effect on extracellular enzyme activity. Pedobiol 54:71-78. https://doi.org/10.1016/j.pedobi.2010.10. 001

Gómez JA (2017) Sustainability using cover crops in Mediterranean tree crops, olives and vines - challenges and current knowledge. Hung Geogr Bull 66:13-28. https://doi.org/10.15201/hungeobull.66.1.2

Gómez JA, Sobrinho TA, Giráldez JV, Fereres E (2009) Soil management effects on runoff, erosion and soil properties in an olive grove of Southern Spain. Soil Tillage Res. 102:5-13. https://doi.org/10. 1016/j.still.2008.05.005

Gómez JA, Guzmán G, Vanwalleghem T, Campos M, Giráldez JV (2010) Proterra y Biosuelo, siete años de ensayos de cubiertas vegetales para control de la erosión en un olivar de verdeo. Agricultura 935:910-915

Gómez JA, Infante AJ, González MM, Vanwalleghem T, Taguas VE, Lorite TIJ (2014) Olive cultivation, its impact on soil erosion and its progression into yield impacts in southern Spain in the past as a key to a future of increasing climate uncertainty. Agriculture 4:170-198. https://doi.org/10.3390/agriculture 4020170

Hakansson I, Lipiec J (2000) A review of the usefulness of relative bulk density values in studies of soil structure and compaction. Soil Till Res 53:71-85. https://doi.org/10.1016/S0167-1987(99)00095-1

Kandeler E (1995) Potential Nitrification. In: Schinner F, Öhlinger R, Kandeler E, Margesin R (eds) Methods in soil biology. Springer, Heidelberg, p 426

Kandeler E, Palli S, Stemmer M, Gerzabek MH (1999) Tillage changes microbial biomass and enzyme activities in particle-size fractions of a Haplic Chernozem. Soil Biol Biochem 31:1253-1264. https://doi. org/10.1016/S0038-0717(99)00041-3

Karydas CG, Sekuloska T, Silleos GN (2009) Quantification and sitespecification of the support practice factor when mapping soil erosion risk associated with olive plantations in the Mediterranean island of Crete. Environ Monit Assess 149:19-28. https://doi.org/10. 1007/s10661-008-0179-8

Kraushaar S, Herrmann N, Ollesch G, Vogel HJ, Siebert C (2014) Mound measurements - quantifying medium-term soil erosion under olive trees in Northern Jordan. Geomorphology 213:1-12. https://doi.org/ 10.1016/j.geomorph.2013.12.021

Lavee S, Haskal A, Avidan B (2012) The effect of planting distances and tree shape on yield and harvest efficiency of cv. Manzanillo table olives. Sci Hortic 142:166-173. https://doi.org/10.1016/j.scienta. 2012.05.010

Leys A, Govers G, Gillijns K, Poesen J (2007) Conservation tillage on loamy soils: explaining the variability in interrill runoff and erosion reduction. Eur J Soil Sci 58(6):1425-1436. https://doi.org/10.1111/ j.1365-2389.2007.00947.x

Lindstrom MJ, Onstad CA (1984) Influence of tillage systems on soil physical parameters and infiltration after planting. J Soil Water Conserv 39:149-152

López VM, Álvarez S (2018) Stability and patterns of topsoil water content in rainfed vineyards, olive groves, and cereal fields under different soil and tillage conditions. Agric Water Manage 201:167176. https://doi.org/10.1016/j.agwat.2018.02.004

Madejón E, Murillo JM, Moreno F, López MV, Alvaro FJ, Cantero C (2009) Effect of long-term conservation tillage on soil biochemical properties in Mediterranean Spanish areas. Soil Till Res 105:55-62. https://doi.org/10.1016/j.still.2009.05.007

Makoi JHJR, Ndakidemi PA (2008) Selected soil enzymes: examples of their potential roles in the ecosystem. Afr J Biotechnol 7:181-191

Makoi JHJR, Chimphango SB, Dakora FD (2010) Elevated levels of acid and alkaline phosphatase activity in roots and rhizosphere of cowpea (Vigna unguiculata L. Walp.) genotypes grown in mixed culture and at different densities with sorghum (Sorghum bicolar L.). Crop Pasture Sci 61:279-286. https://doi.org/10.1071/CP09212

MAPA (1986) Métodos Oficiales de Análisis. Tomo III Secretaria General Técnica del Ministerio de Agricultura Pesca y Alimentación (MAPA), Madrid, Spain.

Martínez CJA, Ramos MC, Ribes DM (2002) Soil erosion caused by extreme rainfall events: mapping and quantification in agricultural plots from very detailed digital elevation models. Geoderma $105(1-$ 2):125-140. https://doi.org/10.1016/S0016-7061(01)00096-9

Melero S, Madejón E, Ruiz JC, Herencia JF (2007) Chemical and biochemical properties of a clay soil under dryland agriculture system as affected by organic fertilization. Europ J Agron 26:327-334. https://doi.org/10.1016/j.eja.2006.11.004

Milgroom J, Soriano MA, Garrido JM, Gómez JA, Fereres E (2007) The influence of a shift from conventional to organic olive farming on soil management and erosion risk in Southern Spain. Renew Agr Food Syst 22:1-10. https://doi.org/10.1017/S1742170507001500

Mohamadi AM, Kavian A (2015) Effects of rainfall patterns on runoff and soil erosion in field plots. Int Soil Water Conserv Res 3:273281. https://doi.org/10.1016/j.iswcr.2015.10.001

Morgan RPC (1995) Soil erosion and conservation, Second edn. Longman, Essex

Nivelle E, Verzeaux J, Habbib H, Kuzyakov Y, Decocq G, Roger D, Lacoux J, Duclercq J, Spicher F, Nava SJE, Catterou M, Dubois F, Tetu T (2016) Functional response of soil microbial communities to tillage, cover crops and nitrogen fertilization. Appl Soil Ecol 108: 147-155. https://doi.org/10.1016/j.apsoil.2016.08.004

Oweis T, Hachum A (2009) Water harvesting for improved rainfed agriculture in the dry environments. In: Wani SP, Rockstrom J, Oweis T (eds) Rainfed Agriculture: Unlocking the Potential. CAB International, Oxfordshire, pp 164-181 
Palese AM, Vignozzi N, Celano G, Agnelli AE, Pagliali M, Xiloyannis C (2014) Influence of soil management on soil physical characteristics and water storage in a mature rainfed olive orchard. Soil Till Res 144:96-109. https://doi.org/10.1016/j.still.2014.07.010

Panagos P, Ballabio C, Borrelli P, Meusburger K, Klik A, Rousseva S, Tadic MP, Michaelides S, Hrabalíková M, Olsen P, Aalto J, Lakatos M, Rymszewicz A, Dumitrescu A, Beguería S, Alewell C (2015) Rainfall erosivity in Europe. Sci Total Environ 511:801-814. https://doi.org/10.1016/j.scitotenv.2015.01.008

Piacentini T, Galli A, Marsala V, Miccadei E (2018) Analysis of soil erosion induced by heavy rainfall: a case study from the NE Abruzzo hills area in central Italy. Water 10:1314. https://doi.org/ 10.3390/w10101314

Raglione M, Toscazo P, Angelini R, Spadoni M, De Simone C, Lorenzini $P$ (1999) Olive yield and soil loss in hilly environment of Calabria (Southern Italy). Influence of permanent cover crop and ploughing. In: Bech J (ed) Analysis of from a physical based model. 6-th International Meeting on Soils with Mediterranean Type of Climate, Barcelona, pp 1038-1040

Ramos MC, Martínez CJA (2009) Impacts of annual precipitation extremes on soil and nutrient losses in vineyards of NE Spain. Hydrol Process 23:224-235. https://doi.org/10.1002/hyp.7130

Ramos MC, Martínez CJA (2015) Soil water content, runoff and soil loss prediction in a small ungauged agricultural basin in the Mediterranean region using the soil and water assessment tool. J Agric Sci 153(3):481-496. https://doi.org/10.1017/ S0021859614000422

Rodrigues MÂ, Dimande P, Pereira EL, Ferreira IQ, Freitas S, Correia CM, Muntinho PJ, Arrobas M (2015) Early-maturing annual legumes: an option for cover cropping in rainfed olive orchards. Nutr Cycl Agroecosyst 103:153-166. https://doi.org/10.1007/ s10705-015-9730-5

Rodríguez PCR, Durán ZVH, Francia MJR, Martín PFJ, Moreno MF, García TIF (2018) Organic olive farming in Andalusia, Spain. A review. Agron Sustain Dev 38:20. https://doi.org/10.1007/s13593018-0498-2

Roldán A, Caravaca F, Hernández MT, García C, Sánchez BC, Velásquez M, Tiscareno M (2003) No-tillage, crop residue additions and legume cover cropping effects on soil quality characteristics under maize in Patzcuaro watershed (Mexico). Soil Till Res 72: 65-73. https://doi.org/10.1016/S0167-1987(03)00051-5

Roldán A, Salinas GJR, Alguacil MM, Diaz E, Caravaca F (2005) Soil enzyme activities suggest advantages of conservation tillage practices in sorghum cultivation under subtropical conditions. Geoderma 129:178-185. https://doi.org/10.1016/j.geoderma.2004.12.042

Sánchez MD, Paniza CA (2015) The olive monoculture in the south of Spain. Eur J Geogr 6:16-29

Sánchez MS, Castro J, Alonso PE, Alonso PJL, García BJM, Talavera M, Durán ZVH (2015) Tillage and herbicide decrease soil biodiversity in olive orchards. Agron Sustain Dev 35:691-700. https://doi.org/ 10.1007/s13593-014-0266-x

Seubert S, Fernández MS, Philipp A, Hertig E, Jacobeit J, Vogt G, Paxian A, Paeth H (2014) Mediterranean climate extremes in synoptic downscaling assessments. Theor Appl Climatol 117:257-275. https://doi.org/10.1007/s00704-013-0993-y

Simoes PM, Belo AF, Pinto CC, Pinheiro AC (2014) Natural vegetation management to conserve biodiversity and soil water in olive orchards. Span J Agric Res 3:633-643. https://doi.org/10.5424/ sjar/2015132-6252

Sinsabaugh RL, Lauber CL, Weintraub MN, Ahmed B, Allison SD, Crenshaw C, Contosta AR, Cusack D, Frey S, Gallo ME (2008) Stoichiometry of soil enzyme activity at global scale. Ecol Lett 11: 1252-1264. https://doi.org/10.1111/j.1461-0248.2008.01245.x

Sola GRR, Castillo RFJ, Jiménez JF, Blanco RGL, Castro GS, Gil RJA (2017) Olive Actual "on Year" Yield forecast tool based on the tree canopy geometry using UAS imagery. Sensors 17:1743. https://doi. org $/ 10.3390 / \mathrm{s} 17081743$

Soriano MA, Álvarez S, Landa BB, Gómez JA (2014) Soil properties in organic olive orchards following different weed management in a rolling landscape of Andalusia, Spain. Renew Agr Food Syst 29:8391. https://doi.org/10.1017/S1742170512000361

Stavi I, Bel G, Zaady E (2016) Soil functions and ecosystem services in conventional, conservation, and integrated agricultural systems. A review. Agron Sustain Dev 36:32. https://doi.org/10.1007/s13593016-0368-8

Subbulakshmi S, Saravanan N, Subbian P (2009) Conventional tillage vs. conservation tillage - a review. Agric Rev 30:56-63

Sujatha DV, Kavitha P, Naidu MVS (2017) Influence of green manure and potassium nutrition on soil potassium fractions and yield of rice crop. Int J Curr Microbiol Appl Sci 6:13-23. https://doi.org/10. 20546/ijcmas.2017.611.002

Tubeileh A, Turkelboom F, Al-Ibrahem A, Thomas R, Tubeileh KS (2014) Modelling the effects of soil conditions on olive productivity in Mediterranean hilly areas. Int J Agron 672123:1-12. https://doi. org/10.1155/2014/672123

Vance ED, Brookes PC, Jenkinson DS (1987) An extraction method for measuring soil microbial biomass C. Soil Biol Biochem 19:703707. https://doi.org/10.1016/0038-0717(87)90052-6

Vanwalleghem T, Infante AJ, González MM, Soto FD, Gómez JA (2011) Quantifying the effect of historical soil management on soil erosion rates in Mediterranean olive orchards. Agric Ecosyt Environ 142: 341-351. https://doi.org/10.1016/j.agee.2011.06.003

Veum KS, Goyne KW, Kremer RJ, Miles RJ, Sudduth KA (2014) Biological indicators of soil quality and soil organic matter characteristics in an agricultural management continuum. Biogeochem 117:81-99. https://doi.org/10.1007/s10533-013-9868-7

Wischmeier WH, Smith DD (1978) Predicting rainfall erosion losses: a guide to conservation planning, USDA-ARS Agric. Handbook, 537, Washington, USA.

Yu Y, Loiskandl W, Kaul HP, Himmelbauer M, Wei W, Chen LD, Bodner G (2016) Estimation of runoff mitigation by morphologically different cover crop root systems. J Hydrol 538:667-676. https:// doi.org/10.1016/j.jhydrol.2016.04.060

Zhang N, He X, Gao Y, Li Y, Wang H, Ma D, Zhang R, Yang S (2010) Pedogenic carbonate and soil dehydrogenase activity in response to soil organic matter in Artemisia ordosica community. Pedosphere 20:229-235. https://doi.org/10.1016/S1002-0160(10)60010-0

Zuber SM, Villamil MB (2016) Meta-analysis approach to assess effect of tillage on microbial biomass and enzyme activities. Soil Biol Biochem 97:176-187. https://doi.org/10.1016/j.soilbio.2016.03.011

Publisher's note Springer Nature remains neutral with regard to jurisdictional claims in published maps and institutional affiliations. 